Crook, M., Crook, T. (2015) Ballot papers and the practice of elections: Britain, France and the United States of America, c. 1500-2000', Historical Research, 88 (241), pp. 530-561.

DOI: https://doi.org/10.1111/1468-2281.12102

This document is the authors' Accepted Manuscript.

License: https://creativecommons.org/licenses/by-nc-nd/4.0

Available from RADAR: https://radar.brookes.ac.uk/radar/items/1cd7751d-2874-428e-b6d6-5a84d885da0e/1/

Copyright (C) and Moral Rights are retained by the author(s) and/ or other copyright owners unless otherwise waived in a license stated or linked to above. A copy can be downloaded for personal non-commercial research or study, without prior permission or charge. This item cannot be reproduced or quoted extensively from without first obtaining permission in writing from the copyright holder(s). The content must not be changed in any way or sold commercially in any format or medium without the formal permission of the copyright holders. 


\section{BALLOT PAPERS AND THE PRACTICE OF ELECTIONS: BRITAIN, FRANCE AND THE UNITED STATES OF AMERICA, c. 1500-2000}

Two technologies have come to define the act of voting in modern democracies: the ballot paper and the ballot box. Both are easy to use and both secure secrecy, preventing intimidation, bribery and corruption, at least in theory (practice is another matter). ${ }^{1}$ 'For many people today, democracy is epitomized by the image of a voter dropping a piece of paper into a ballot box', write the political scientists Massicotte, Blais and Yoshinaka in their 2004 global survey of election laws. 'Ballot papers and ballot boxes', they add, 'embody one of the few unchallenged principles governing elections - secrecy. ${ }^{2}$ Few would disagree. In Britain certainly, media coverage of domestic and foreign elections is routinely accompanied by pictures of this sort (of electors queuing up to vote; of papers spilling onto tables, ready to be counted; and so on); and no one speaks up for open voting any more.

But when and where, precisely, did ballot papers become central to the practice of elections, democratic or otherwise? And what distinguishes the papers of today from those of the past? What, in fact, is a 'ballot paper' - what is it for? Remarkably, given the iconic status of the ballot paper, these questions have yet to be explored with the rigour they deserve. They have not been entirely neglected. The most thorough work has been undertaken on the US, which is ironic perhaps, since this was the first country to abandon ballot papers, as some states began to adopt mechanical and later electronic means of voting. ${ }^{3}$ Otherwise this earlier electoral technology has been considered only indirectly, via histories of voting in secret. ${ }^{4}$

Accordingly, when it comes to recovering ballot-related innovations, colonial Australia takes pride of place in the existing historiography. It was here, after all, where in 1856 the secret ballot was first practised, combining pencils, standardized papers, boxes and cubicles. ${ }^{5}$ A recent article has shown that this was a transnational achievement, even if it would go on to become Australia's most famous democratic export. ${ }^{6}$ The pioneer, Henry S. Chapman, was a British-born radical and he was familiar with US and French practices by the time he arrived in Victoria in 1854. Just as importantly Chapman's particular combination of elements - printed papers, cubicles and so on - was first proposed in revolutionary France in 1794 by the lawyer JacquesVincent Delacroix. Still, the Australians got there first. As John Markoff has argued, the global 'periphery' was much ahead of the 'core' in this respect, as in so many others (e.g. universal female suffrage, which was first introduced in New Zealand in 1893). ${ }^{7}$ One reason for this, he suggests, is that in places like Australia there was greater freedom for innovation given the absence of long-established elites and entrenched traditions, interests and institutions.

Yet, as will be argued here, any rigorous history of the ballot paper needs to make use of two analytical distinctions. The first is straightforward: the need to distinguish between the practice of using of papers per se, and the practice of using them in secret. In fact, the use of ballot papers - including, it should be emphasized, the use of papers on a mass scale - long predates the emergence of fully secure, privatized voting. Recovering this earlier history allows not only for a better understanding of why papers were used at all, but also for a more critical appreciation of some commonplace assumptions. Ballot papers, for instance, have not always been technologies of 'electoral purity', as it was sometimes put in the nineteenth century. Quite the contrary: for a time at least, they were crucial to an intensification of corruption, as electoral 
authorities and nascent political parties adjusted to the demands of an expanding franchise. Equally, it also helps to clarify the contribution that Australia made in the mid-1850s, for ballot papers were already a feature of elections elsewhere in the world, including standardized, regulated ones.

The second distinction is between considerations of electoral practice on the one hand, and those of political principle on the other. Both comprise what we might call electoral culture and it is not an easy distinction to make. But it is a useful one in the case of balloting and for one key reason: simply because contemporaries themselves recognised its practical utility whilst also debating the ethical-political merits of open and secret voting. As work within an emergent 'material turn' suggests, practical considerations - considerations, that is, of logistics, technology and discipline - are just as important as values, beliefs and identities when it comes to understanding how societies function. Crudely, things, even 'little' things like paper, make possible 'big' ideas, structures and identities. Patrick Joyce, for instance, has recently written of how the emergence of the modern British imperial state was premised on an ability to knit together over time and space material-bureaucratic traces such as letters, forms and documents. The Raj was partly an archival achievement. ${ }^{8}$ In our case, humble technologies though they were, ballot papers made possible the enactment of more inclusive franchises and more organized, party-based forms of electoral contestation. In both cases minor practices and material details made all the difference, as contemporaries so evidently realized. Ultimately, they made possible the democratic principle of 'popular sovereignty' - an immense abstraction came to pivot on a mass of regulated paperwork.

Equally, as Frank Trentmann has emphasized, though there may be a materiality to politics there is also a politics of materiality. The material world, he argues, is not simply a backdrop to human affairs. Rather, it is altogether more active than this, enabling society to function but shaping it in particular ways; and because of this our material-infrastructural environment also doubles an object of political critique and appropriation. The examples he gives are many and include commodity-based consumer activism and the politics of municipal water supplies. Material things, he concludes, function 'as a conduit of political processes that helps shape (and not just reflect) political identities, concerns and fields of action." This is certainly true of balloting, and especially secret balloting and the mobilization of pens, cubicles and official papers, which proved immensely controversial. In fact, it seems that wherever secrecy was introduced it provoked a clamour of dissenting voices that appealed to matters of principle, as Hubertus Buchstein's superb account suggests. ${ }^{10}$ The trouble was that the kind of voter independence most could agree was important was simply not taking place in practice. Reluctantly, secrecy was embraced. Only in the second half of the twentieth century was secrecy posited as a good in and of itself; only then was it hailed as an inevitable feature of 'political modernization'. Put another way, considerations of practice trumped those of principle, at least initially.

We develop this analysis by focusing on three of Markoff's 'core' nations, Britain, France and the US. This is a partial selection of course, and each country embraced a fully secure ballot at different points in time: Britain in 1872, albeit not at all levels; the vast majority of US states by 1900; and France in 1913. In the meantime Belgium adopted the secret ballot in 1877, Italy in 1882, Denmark in 1901 and Germany in 1913. Why, then, focus on these three countries? Once again, it is important not to be wholly distracted by the advent of secrecy, important though this was. Size 
mattered and the US and France were the first to pioneer paper balloting on a largescale - indeed, they did so partly because elections now involved far more voters than before, following their respective revolutions. Surprisingly perhaps, Britain partook of some of these innovations, making for some remarkable commonalities regarding the use and abuse of papers. Furthermore, it was the first nation to adopt the 'Australian ballot' and apply it to a sizeable electorate. The US would do the same, even if as early as the 1890s it was practising alternatives to the use of paper. Later on, France developed its own method of secret voting, or what is now known as the 'ballot and envelope model', the principal paper-based alternative to the Australian model. In short, both pre- and post-secrecy, these were all pioneering states. We begin, however, in the early modern period and with a basic question: why use ballot papers - or balls?

\section{Balloting as last resort: papers, balls, hands and voices}

The practice of using ballot papers on any significant scale first emerged during the early modern period, when it coexisted alongside a host of other practices inherited from the ancient world, the early Christian Church and the city-states of medieval Europe. ${ }^{11}$ In Britain and France the pioneers were town corporations, where the office of mayor in particular might be determined using some form of ballot, cast during an annual assembly (or court) of local elites and councillors. ${ }^{12}$ It remained, however, an exceptional practice throughout this period and indeed on into the eighteenth century. Corporate autonomy was carefully prescribed by royal charter and the dominant method of electing borough personnel involved those assembled indicating their preference either orally - by casting their 'voice' - or by raising a hand, normally in order of social rank. Significant variations emerged, even where there was no resort to balloting. In Woodstock, Oxfordshire, the freemen of the borough were directed to stand either side of the Guild Hall, from where the relative weight of their voices would determine which of the two candidates (selected from the aldermen) would serve as mayor. ${ }^{13}$

Alternatively, in Dijon, Burgundy, where all male householders were enfranchised, voting for the office of mayor took place in a convent near the city's cathedral. One by one, electors would deliver their votes orally, in full view of the officials. ${ }^{14}$

Other examples should be mentioned. A highly ritualized tradition of oral voting developed in Britain for the election of MPs, where voters would declare their choices to a poll clerk, having ventured past a crowd gathered before the hustings. ${ }^{15}$ Likewise, the rotation of parochial officers would be decided openly by a show of hands, commonly in the parish vestry. But besides default resort to publicity, this was an altogether different culture of elections from that which would begin to emerge in the nineteenth century. As Mark Kishlansky has argued, use of the term 'election' is somewhat anachronistic in the early modern context, for what was really at stake was a process of affirmation and confirmation, as opposed to one of conflict and counting. One had a 'voice' rather than a 'vote', so there was no need for technological mediation; and one 'stood' for office, implying open and due acknowledgement of status, rather than 'ran' for office, implying some kind of competition. ${ }^{16}$

Two further points might be made here. The first is that the boundaries between the selection, discussion and election of a candidate (or candidates) might be incredibly porous. This is in stark contrast to today, of course, when these stages are highly regimented and sequential (candidate selection; then election campaign; then polling 
day; then counting). The second is that the dominant assumption was that elections would proceed more or less consensually. In the case of British MPs there was no automatic resort to polling, which would only ensue if the nomination process, completed in public, proved contested; and until the nineteenth century, the majority passed without challenge. ${ }^{17}$ Even in the absence of a challenge, a nomination ceremony was staged, which might include an affirmative 'view' of the crowd, conducted by a show of hands or an acclamation of voices. ${ }^{18}$ Only in the event of a contested selection process was there recourse to the numerical precision of a poll, which might last for weeks. Likewise, at the municipal level, the assumption was that elections would be open, deliberative, but ultimately consensual affairs, where the annual turnover of borough personnel would prove trouble-free, thereby affirming the unity of the local community. ${ }^{19}$ As various studies have demonstrated, there was a widespread aversion towards conflict, if only by way of projecting an image of elite stability to the Crown and social inferiors. ${ }^{20}$

The early use of balloting needs to be understood in precisely this context. Put simply, it was a means of managing elections that had proved, or might prove, unduly fractious and where the hostility of competing factions was such as to render open voting neither practical nor decisive. It was a last resort, adopted only in the unfortunate event of conflict, much as was a polled contest in the British parliamentary context. Balloting assumed one of two forms, both of which could be used to secure secrecy. One was the use of balls, reflecting the origins of the word 'ballot', which derives from the Italian term ballota, the diminutive of balla or ball. ${ }^{21}$ In Aix-en-Provence electors voting for the office of mayor deposited black balls in boxes coloured red and yellow, one for each of the two candidates. ${ }^{22}$ Alternatives such as bullets were also used. In 1677, the Hampshire town of Lymington experimented with the use of coloured bullets, in order, so it was stated, to 'prevent animosities and other inconveniences which may arise at the choice of a fit person to serve as mayor of this town'. ${ }^{23}$

The other principal method was the use of pens and paper. In sixteenth-century Paris the election of the prévôt des marchands (mayor) and échevins (aldermen) was conducted using written ballots, which were prepared by hand and deposited in a box. ${ }^{24}$ Pontefract was among a handful of English towns which adopted some kind of paperbased mechanism. Under a charter granted by James I in 1607, partly designed to quell the 'infinite disputes' of mayoral elections, the burgesses wrote down the name of their preferred candidate on separate pieces of paper, which were then deposited in a box. ${ }^{25}$ A kindred system was practised in Kingston-upon-Thames, where the election of the town's two bailiffs (the highest office, in this case) was conducted using a single piece of paper detailing the names of up to four candidates, which was displayed in a room set apart for the purpose. Each member of 'the fifteen' - the freemen of the Court of Assembly, the governing body - viewed the ballot paper alone and gave his vote by scratching through the name of one of the candidates with a pen. ${ }^{26}$

It is significant that it was principally the office of mayor - the most prestigious and powerful, and so sought after - that gave rise to balloting. Lesser offices, including that of alderman, were normally resolved by the use of hands and voices. Equally, not all balloting was conducted with a view to managing conflict; nor was it always conducted in the context of local assemblies. Deputies to the Estates-General of 1614, the last to meet in France until the end of the ancien régime, were selected in a variety of ways; but the nobility were permitted to submit written papers - or billets - which they also signed. ${ }^{27}$ In general, however, balloting prospered when and where there were 
problems of discord at the local level; and the procedural variations were many. In some towns the use of balloting was itself put to a vote. In 1575, the officials of Poitiers voted out loud to proceed by written ballot in their annual mayoral elections. In so doing, they drew on powers set out in an old statute, which provided that whenever a single candidate sought office the election could proceed aloud; but that when there was more than one candidate the assembly should vote by ballot. It was a tradition that would last only thirty or so years longer: in 1609 , owing to persistent divisions, Henry IV ruled that balloting would henceforth be compulsory. ${ }^{28}$

All of these practices travelled to America, where various local offices were subject to election, from positions on parish vestries and commercial corporations to official seats on counties and towns. In all cases the dominant practice was voting openly, using either hands or voices, in the context of small assemblies of property holders and freemen. ${ }^{29}$ Similarly, the election of state representatives to serve on general assemblies was normally conducted openly. Six of the original thirteen colonies - New York, New Jersey, Maryland, Virginia, North Carolina and Georgia - used a form of oral voting based on British traditions, when and where a poll was required. ${ }^{30}$ Colonial American electoral culture, then, was much the same as in Britain and France, and this included resort to balloting, which was principally practised in New England. Historians such as Robert Dinkin have presented New England as a pioneer of balloting, and it seems it was the first place to practice proxy voting. ${ }^{31}$ Yet, besides French and British precedents, some crucial qualifications should be mentioned. The first is that resort to securing some means of procedural order and numerical precision was reserved for when and where a contest was required, which was generally for the more powerful positions. At the local level, written ballots might be used to elect senior town officers, such as the selectmen and treasurer, but not for the lower positions, such as gravedigger and hog reeve. In these cases there was often only one (perhaps grudging) candidate, elected by oral acclamation or a show of hands. ${ }^{32}$

The second qualification is that balloting did not necessarily entail secrecy. As in Britain and France, resort to balloting was not a matter of principle; more practical considerations were at stake. A case in point is proxy voting, which originated in Massachusetts in the 1630s for the election of the General Court. Previously, all qualified electors had been expected to attend in person at the provincial capital (Boston), where their written ballots would be presented openly and deposited in a hat. The inconvenience of travelling, however, coupled with growing disorder on the day, prompted the practice of allowing freemen to mark their papers at a special town meeting, under the supervision of the selectmen, who would then present them to the Court during the election proper. ${ }^{33}$ The system, then, was not as open as elsewhere; yet it was by no means secret either. Whether delivered in person or prepared at a distance, papers would have to pass through the hands of presiding officials. Indeed, in Rhode Island it was customary for electors to sign their proxy ballots as well. ${ }^{34}$ Meanwhile, illiterate voters had to rely on the literate to inscribe their choices; and these choices would then have to be confirmed orally as their credentials were checked.

In all three countries, then, amidst a culture of elections which was predominantly oral, open and co-optive, there were pockets of balloting, which might be more or less public, even secret, depending on context and occasion. The underlying ideal, however, seems to have been one of communal self-presence and unity, unsullied by discord and recourse to paper, balls and obscure acts of voting. In Britain this would remain the case until the $1830 \mathrm{~s}$, though balloting did receive sporadic support from 
Whigs and radicals. ${ }^{35}$ In France and America, by contrast, it is possible to point a gradual growth in support for balloting over the course of the eighteenth century. In New England towns there was greater resort to written ballots, as local elections became more inclusive and rule-bound; and by the early 1770s, printed papers were being used in Connecticut and Rhode Island for the election of state deputies - a key feature of post-revolutionary electoral culture, as we shall see. ${ }^{36}$ In neighbouring Pennsylvania, an election law of 1706 prescribed a mixed system for the election of state-level offices, whereby a voter could choose to vote openly and orally, or with a written ballot. In 1715, written balloting also spread to North Carolina, which had earlier adopted oral voting. In this case voters were required to sign their papers, though in 1760 the state returned to British-style viva voce polling. ${ }^{37}$

In pre-revolutionary France the written ballot attracted growing levels of support, especially from members of the administrative elite, who viewed it as a means of securing more orderly, accurate outcomes in municipal elections. ${ }^{38}$ The abortive reform of municipal administration undertaken by Laverdy in 1764-5 clearly stipulated the use of ballot papers, while some twenty years later the Brienne law on local government required vote by billet, unless the majority of those present were illiterate. ${ }^{39}$ Yet the issue remained contentious. The Assembly of Notables reconvened in November 1788 to advise on the forthcoming Estates-General was divided on the matter. One section was adamant that voting at all levels should be out loud (à haute voix), principally because it was the honourable, time-honoured thing to do; but two other sections urged that papers, in the interests of precision, should be compulsory at the highest level of the process, when deputies were chosen for Versailles. ${ }^{40}$ In the event, the last elections to be held under the old regime combined the written ballot and oral voting. Voting in the preliminary assemblies was out loud, but at the final stage the employment of a written ballot was prescribed, by which point the electoral system had ensured a more literate gathering. ${ }^{41}$

\section{Balloting as norm: handwritten and printed ballots}

By the second half of the eighteenth century the practice of 'balloting' had become chiefly associated with the use of paper and the practice of writing, rather than the casting of balls. 'Polling' was another matter, especially in Britain, where parliamentary elections continued to be conducted using oral voting, as and when required.

Furthermore, the association was by no means total. In Britain, France and America oral voting had relied - and would continue to rely - on techniques of inscription by way of recording voter preferences and publicising election results. One instance of this is the 'poll books' published in Britain, which emerged following an act of 1696 designed to regulate parliamentary elections. It is not as if paper was wholly absent when and where oral voting took place: even voices might leave traces. Nonetheless, $c .1780$ the use of ballot papers was exceptional; a hundred or so years later ballot papers had become the norm, the dominant means whereby voters registered their choices. Early-modern voices had been exchanged for regulated bits of paper; face-to-face assemblies had been replaced by the mediation of pens, boxes and acts of counting.

How should we explain this remarkable transformation in the material culture of elections? Two broad factors were crucial. The first is a commitment to larger, more inclusive franchises, which meant of course more voters; and in order to make this 
commitment work new mechanisms were sought - of which the ballot paper was only one, it should be emphasized; others included voter registration and the provision of more polling stations. Here we might also note the marked demographic expansion that took place after roughly 1800, supplemented in the US case especially with high levels of immigration. At the same time, more inclusive franchises meant higher levels of voter illiteracy, at least until the onset of universal systems of elementary education. Illiteracy was particularly important in terms of prompting the use of printed rather than written and/or signed papers.

The second factor is the rise of political parties and party-political conflict. In the early modern period, ballot papers had helped to manage unusually contentious elections; but in the nineteenth century, competitive elections became routine, at least for major offices. To be sure, the rise of parties and the generalization of party-based conflict was a protracted process, as numerous studies have detailed. ${ }^{42}$ In revolutionary France and America, parties were initially regarded as a threat to national unity, as devious agents of faction and sectional interests. The US had largely overcome this antipathy by the 1830s, but it lingered much longer in France: it was not until 1889, for instance, when declared candidatures were prescribed by law. The British too were sluggish and sceptical: tens of seats continued to go uncontested in general elections long into the twentieth century. Nonetheless, party-political conflict was slowly but surely institutionalized and this placed a premium on mechanisms that could (a) secure numerical precision and (b) provide some means of managing voters. And in this context, coupled with expanding franchises, ballot papers - printed ones especially had a decided advantage over hands and voices.

This is to offer only two general factors. Just as crucial is the way these factors combined at particular times in particular places, thereby giving rise to significant, if often subtle, variations of development and practice. In fact, the complexities are immense and one way of narrating them would be on a country-by-country basis. Here we have opted to organize our analysis around six key themes. Though this may suppress some sense of national trajectory, it does have the virtue of highlighting the peculiar dynamics and possibilities of the ballot paper as an electoral technology indeed, whether in Britain, France or the US, it amounted to much the same thing: a thin slip of paper. We begin with some key differences of administrative culture and regulatory scope.

1. Spatial-electoral variations. It was in France where written balloting first became a truly national practice; and it did so partly because reformers and radicals were dedicated to realising 'the Nation' as the basis and principle of sovereignty. Uniformity was a political goal in itself, at once a measure and a means of equality. In December 1789 the deputies who had taken control of the Estates-General, and transformed it into a National Constituent Assembly, decided in favour of the wholesale adoption of the billet (later bulletin), to be employed at all levels of the electoral process, together with a broad adult male suffrage. ${ }^{43}$ Surprisingly, few objections were raised against this arrangement; just one deputy made the obvious point that most peasants were illiterate and that the obligation to ask someone else to write names on the ballot paper was an invitation to abuse. ${ }^{44}$ Abuse did in fact occur; but the subsequent elections of 1790 mark a global watershed nonetheless: they were first elections in the world to be conducted according to a mass, uniform commitment to paper. 
The momentous year of 1789 set the pattern for what followed: simply that when voting practices changed in France they did so on a national basis. And change they did, especially during the period 1789-1815. Following the collapse of the monarchy in 1792, the still-born Constitution of 1793 offered all French voters a choice in how they delivered their verdicts, either viva voce or by billets. ${ }^{45}$ However, the pressure exerted against minorities in viva voce elections, which was roundly condemned by resurgent moderates after 1794, meant that the obligation to vote by written ballot paper was reasserted in the Constitution of 1795. Napoleon introduced further innovations. The 'plebiscites' of 1800, 1802, 1804 and 1815, in an echo of British polling practices, required voters to record their name in a public register, indicating their acceptance or rejection of a constitutional proposition. ${ }^{46}$ Yet balloting remained in place, even under Napoleon: when his administration re-established the election of parliamentary deputies in 1802, the practice of using written ballots resumed. It was then retained by the restored Bourbon and July monarchies, and all the regimes that followed.

In Britain and the US, by contrast, balloting was adopted in a decidedly more lumpy fashion. In Britain there was uniformity perhaps for certain kinds of election, but not for all elections. Indeed, it was not until the 1948 Representation of the People Act when Britons began using the same paper-based method for all elections. Nonetheless, in terms of balloting per se, the 1830s constitute the crucial decade. Balloting for parliamentary elections was first debated in the Commons in 1830 and was even considered for inclusion in the Great Reform Act of 1832. A majority of MPs would remain unconvinced for another four decades, preferring the often tumultuous occasion of open polling at least once every seven years; but this did not preclude considerable experimentation at the local level.

There were two key areas of innovation. One of these was the annual election of poor law authorities, in particular parish vestries and, after 1834, Boards of Guardians. The Sturges Bourne acts of 1818 and 1819 had imposed some discipline on increasingly unruly parish elections, among other things allowing the formation of 'select' vestries, which effectively barred popular participation. ${ }^{47}$ It also provided for an oral poll if required, replacing the customary method of voting by a show hands. In 1831, however, the radical MP John Hobhouse passed his Select Vestry Act, undoing plural voting, extending the vote to all ratepayers and allowing for the use of papers and boxes. By the early 1840 s eight parishes had adopted the act, including some of the larger metropolitan ones, such as Marylebone, where more than 3,000 voters turned out in the elections of 1833 , and over 4,000 in $1834 .{ }^{48}$ Similarly, but more importantly, given its national scope, the 1834 Poor Law Act enforced the election of Boards of Guardians using ballot papers printed by local Poor Law Unions.

The second area was the reform of boroughs. The 1835 Municipal Corporations Act introduced voting papers, as well as a uniform ratepayer franchise and an enlarged number of councillors, a third of whom were now subject to annual election. ${ }^{49}$ As John Phillips suggested, though the balloting provisions of the 1835 act attracted little debate in Parliament, the rationale advanced by its sponsors such as Lord John Russell was one of practicality. ${ }^{50}$ In most parliamentary contests each elector possessed two votes and was presented with three or four candidates; but the new borough arrangements meant that the total number of candidates might exceed 100 in large towns and cities. The introduction of ward divisions and the use of papers was thus presented as a more orderly and efficient alternative to relying on traditional viva voce methods. Between 
them, poor law and municipal innovations provided the model for subsequent local authorities and their means of election: local Boards of Health after the 1848 Public Health Act; vestry and district boards in London following the 1855 Metropolis Management Act; and School Boards after the 1870 Education Act. ${ }^{51}$

In the US the situation was still more complex. As in France, the widespread diffusion of paper balloting was a post-revolutionary phenomenon, where it featured in the constitutions of both the former colonies and the new states of the West. Yet - and unlike France - there was no central-federal prescription concerning voting methods. It was not until 1871 when the first national law was enacted, which prescribed either 'written or printed ballots', though this was not subject to strict enforcement. ${ }^{52}$ In the absence of any federal determination, differences blossomed both between and within states, at the town and county levels, and for different kinds of election. New York's first constitution (1777) permitted the use of written balloting for the election of the governor and lieutenant-governor. Implemented in 1788, it was extended to the election of the state legislature in 1797 and to town elections in $1809 .{ }^{53}$ Similarly, New Jersey adopted paper balloting only tentatively, on a county-by-county basis: by 1788 nine of the thirteen counties had opted for this method of voting; by 1800 it was in use in all thirteen. ${ }^{54}$ Other states which provided for balloting included Vermont (1793), Ohio (1802), Indiana (1816), Michigan (1835) and Minnesota (1858).

When and where it was adopted, paper balloting was justified on various grounds, including those of convenience in the context of an expanding franchise. By the 1840s most of the older states had adopted a more or less (white) male suffrage; and the new states did the same. However, a strong attachment to British parliamentary tradition persisted in places. Texas up to 1848; Virginia up to 1867; and Oregon up to 1872: all of these states practised viva voce voting, where it was defended on the grounds that it enabled the exercise of the franchise in an honourable fashion. ${ }^{55}$ Some states even switched back and forth. Illinois alternated between oral voting and paper balloting during the period 1813 to 1829 , before finally settling on the latter in 1848 . Kentucky adopted the written ballot in 1792, but reverted to viva voce methods just seven years later. In 1850 the General Assembly assumed the power to determine the method of voting and thereafter balloting became more common; yet oral polling persisted in some counties until 1891, when it was abandoned across the state.

2. Voting in public: The French scored another first in 1795: its new Constitution of that year contained the first explicit reference to a 'secret vote' (scrutin secret). ${ }^{56}$ But this would remain only a nominal gesture, for in practice, as in Britain and the US, balloting would continue to take place in a public fashion, in assemblies of varying size and location. There was as yet no pronounced desire to introduce partitions or cubicles to shield the act of marking or writing a paper. Nor was there any generalized desire for technologies such as envelopes, which might hide the paper as it was deposited in a receptacle. Only in places do we find exceptions to the dominant norm of more or less publicly cast ballots. In Massachusetts, for instance, a coalition of Free Soilers and Democrats elected to the General Court passed a law in 1851 prescribing the use of envelopes to conceal papers. Even here, however, the measure was short-lived and on returning to power in 1853 the Whig party made the use of envelopes optional, invoking as they did so the integrity and 'honour' of open voting. ${ }^{57}$

Further exceptions emerged in Britain. After 1834, poor law electors were required fill out their voting papers in the confines of their home, from where they were 
collected. This uniquely domesticated form of voting certainly made for order, in contrast to the sometimes volatile vestry elections that had taken place earlier. The papers themselves might note that they were being used so that an elector could vote 'without the loss of his time' or other 'inconveniences usually incurred by attending to give his Vote at a polling place, at a distance from his home. ${ }^{58}$ Local Boards of Health were subsequently elected in the same fashion.

Yet, even in the case of the poor law method, voters were required to sign their paper and initial the names of those they wished to see elected, thus exposing their identity to the eyes of the returning officer and candidates, when their votes were 'cast up' in the Union board room. Borough electors also had to sign their papers, which were presented in person to the electoral officials at the town hall. The same disregard for secrecy is evident in France and the US. In France, papers were either written or presented in a public assembly (assemblée électorale), commonly convened in a church, courthouse or a town hall, where they would be deposited in a boite de scrutin or urne. Similarly, in the US, papers were deposited in the presence of assemblies of fellow electors and officials, who would gather in and around a church, courthouse, mill or schoolhouse. By the mid-century, the use of 'voting windows' was common across the US, a practice which normally entailed electors presenting their papers on a platform to officials who were set apart in an interior room or behind a desk of some sort. ${ }^{59}$ Polling places continued to vary and now extended to post offices, hotels and railway sheds; and in the mid-West especially, the verandas of houses owned by landowners.

3. Handwritten and printed papers: What of the papers themselves? Crudely, we can distinguish between handwritten papers and printed papers, and point to the gradual displacement of the former (handwritten) by the latter (printed). In France, the commitment following the Revolution and up to 1848 was to use handwritten papers, composed in the midst of an electoral assembly. During the early 1790s, participants were called in alphabetical order to handwrite their paper - normally on a table, in close proximity to the officials - and then fold it, prior to its insertion into an urne. Voters swore an oath promising to exercise independent judgement, but intense lobbying would be conducted by those competing for office. ${ }^{60}$ Furthermore, given the expanded electorate, this method invariably met with the problem of illiterate voters. In the end the task of assisting illiterate voters was entrusted to elected scrutineers, who also supervised and counted the votes; but disputes might ensue about whether an illiterate voter's wishes had been respected. ${ }^{61}$ It was also expressly forbidden to prepare ballot papers in advance. Instead they had to be completed at the assembly, on squares of paper issued by officials (Fig 1.). There was no possibility of using printed ballots, a practice in any case unsuited to the series of votes that were taken. For, to make matters still more complicated, up to three rounds of balloting were prescribed in the search for absolute majorities. 


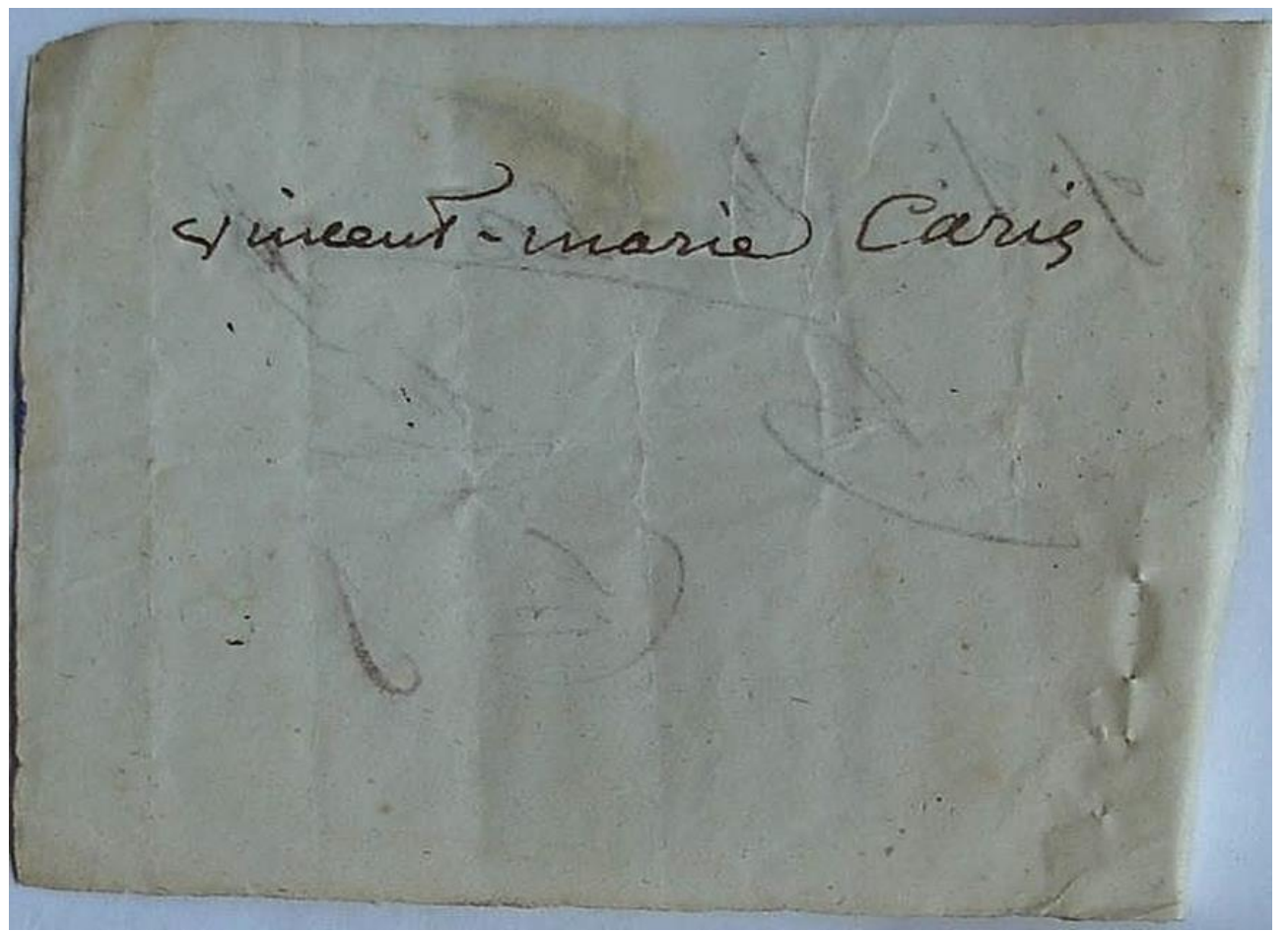

Figure 1: A ballot paper from a set of primary elections held during the Napoleonic regime in Morbihan in 1807, which reads, simply, 'Vincent-Marie Caris'. The normal course was to destroy all papers following the count. This paper survived owing to suspicions that it was pre-written for use at a cantonal assembly. Archives Nationales [AN] F1cIII, Morbihan 2, Protestation, Guémené, 21 Aug. 1807.

In this context to insist on written ballots was hugely problematic, giving rise to arguments that viva voce voting was not only ethically superior - more open, manly and honourable - but also more practical. ${ }^{62}$ A mass of names was needed for the multiple posts that had to be filled, from local councillors to parliamentary deputies.

Furthermore, during the first year of the Revolution, in an endeavour to discourage vote-rigging, twice as many individuals had to be named as vacant places: the so-called 'double list'. At Parizot, a rural canton in the southern department of the Aveyron, scrutineers apologized for taking a whole day to count first-round votes, which offered 'a huge range of names ... with different nominations appearing on every single billet ${ }^{63}$ Ballot papers were often poorly written by those with only a basic grasp of handwriting, whilst making a distinction between persons who shared the same family name could be immensely difficult. The case of two individuals from Paris, both named Bourdon, who sought election in the department of the Oise in 1792, was the source of a celebrated dispute. ${ }^{64}$ Under the Directory, procedural reforms were introduced in order to expedite the process of administering billets, including the abolition of double lists and the reduction to two rounds of voting. Later on, under the Bourbon and July monarchies, the problems associated with illiteracy greatly diminished, given the narrow franchise that operated after 1814 (by the early 1840s it extended to only 250,000 property-holders). But in France, for almost sixty years following the Revolution, when balloting took place it did so using handwritten papers to the explicit exclusion of any prepared before or outside an assembly. 
It was only in 1848 when printed bulletins began to replace handwritten ballots. Amidst the growth of a partisan press and embryonic political parties, they would soon become the norm. The crucial event that prompted the widespread adoption of printed papers was the creation of the Second Republic and the advent of mass legislative elections. Despite initial misgivings, the Provisional Government of 1848 eventually agreed that the use of printed ballots was the best means of facilitating a franchise which now extended to roughly nine million male voters, by far the biggest electorate in the world at this point. Other innovations included the abolition of multiple rounds of voting and the stipulation (made in 1852) that all papers should be completed or collected outside of polling stations (bureaux de vote) ${ }^{65}$

Even so, French voters could still prepare their own handwritten papers and they would continue to do until the 1920s. A similar dynamic had earlier been established in Britain and the US, where printed papers became dominant, but not to the total exclusion of handwritten ones, or indeed printed ones modified by the elector. In each case, it was accompanied by the development of more or less organised party systems, complete with parties and party agents, and growing levels of partisan loyalty. In Britain voters using the post-1834 poor law method had to use a paper printed by the local Union, an early instance of the official papers that would become standard after 1872. In the absence of precise statutory guidance, however, electors under Hobhouse's act of 1831 and the 1835 Municipal Corporations Act were permitted to pen their own, even if the vast majority preferred to use those printed either by parties or by vestries and municipal corporations (Fig. 2). 


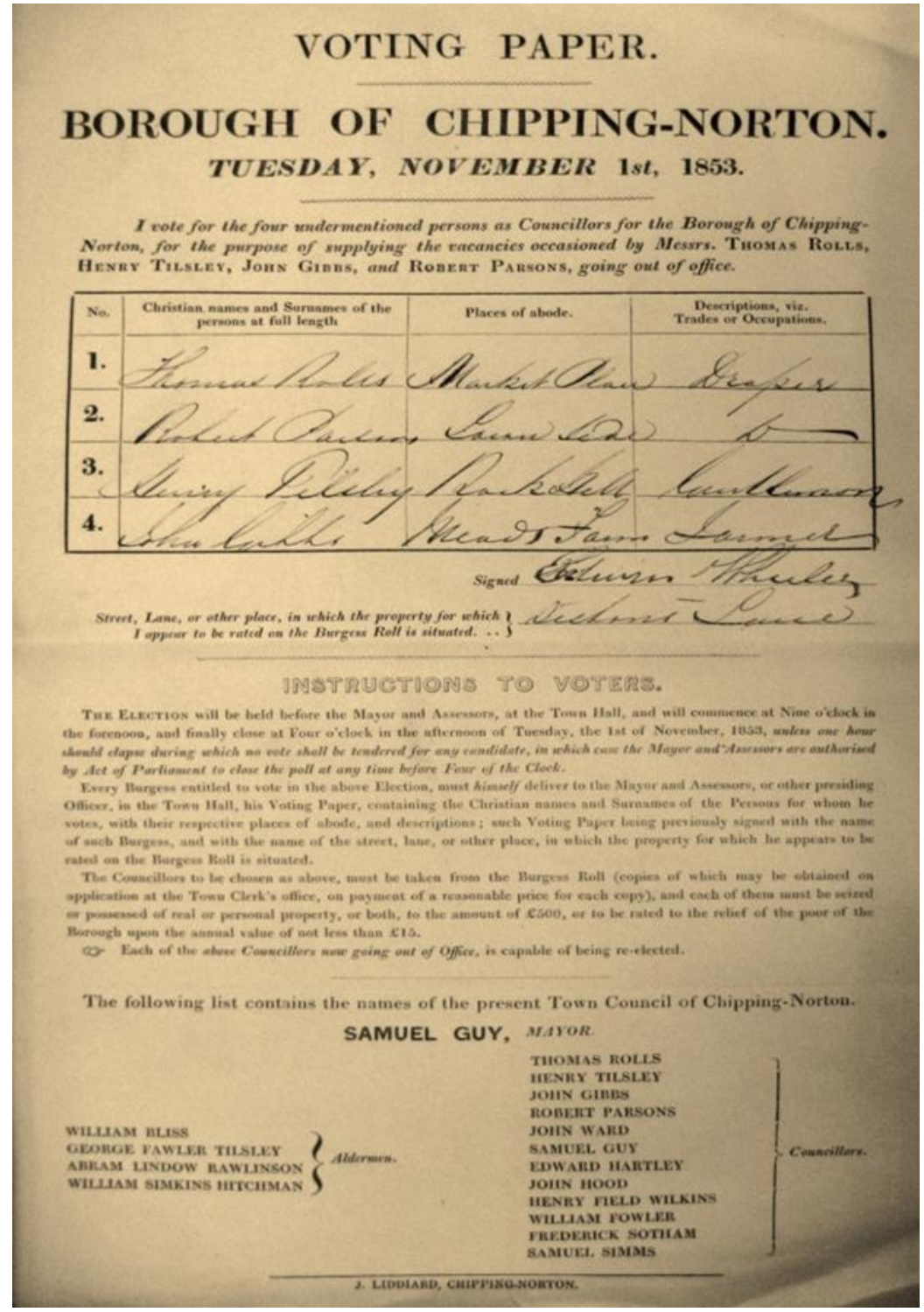

Figure 2: A voting paper cast in a borough election in Chipping Norton in November 1853. It is one of a bundle of sixty held in the Oxfordshire Record Office, BOR1/7/A3/1, for this particular election. Under the 1835 Act all papers had to be kept for six months and were open to inspection by any burgess on payment of one shilling.

It was in the US where the use of printed, partisan 'tickets' really took off and it did so very early - a significant point of difference with France, despite the latter's commitment to paper-based balloting. Initially it was written balloting that predominated, but in most US states this was soon supplemented by the provision of printed papers (or tickets) detailing a full slate of candidates. A Tennessee statute of 1796 embraced both kinds of ballot, defining a 'ballot' as 'a ticket or scroll of paper, purporting to express the voter's choice, given by the voter to the officer or person holding an election, to be put into the ballot box. ${ }^{, 66}$ In other states the transition was more protracted. In Massachusetts it took a ruling of the state supreme court to prompt the decline of handwritten ballots. In 1829, an elector submitted a printed paper containing the names of fifty-five candidates. The ballot was rejected; but on appeal the 
court ruled that printed ballots were 'written ballots' within meaning of the state constitution; and thereafter partisan papers become the norm. ${ }^{67}$

Part of the rationale was to circumvent the lengthy process of filling out multiple papers detailing dozens of names and to help the growing number of illiterate voters; ${ }^{68}$ but printed papers also afforded more control to parties and party agents, just as they did in Britain and France. The result was a proliferation of tickets, though much depended on the number and nature of the contests being fought and state-level regulations. If the only office contested was the presidency or governorship then parties needed to print just one ticket for the entire state; but if members of Congress were being elected as well, then different tickets for each congressional district were required; and so on, down to the level of urban wards in some cases. The result was that by the mid-century parties had to print hundreds of different tickets, each of which might be appropriate for only a handful of polling places. Voters in fact might be overwhelmed with tickets. In those states where election laws demanded a separate ticket for every level of government, such as New York and California, voters were presented with 'bundles' of tickets which required depositing in multiple boxes. In the 1864 general election in New York there were five boxes, one each for the presidential, congressional, state office, assembly district, and city and county contests. ${ }^{69}$

4. Paper-based corruption: In all three countries the advent of balloting rendered voting more complex from a material-practical point of view. In place of voices and hands, there were now papers and a mixed set of agents charged with designing, distributing, receiving and counting them; and then there was the voter himself. Corruption crept in at each and every point. Ballot papers may have enabled the enactment of more inclusive franchises, but they also enabled new kinds of party-based 'trickery'. The administration of papers constituted one point of vulnerability. Registration fraud and repeat voting; the rejection and contestation of papers; or just crude maladministration, such as 'misplacing' boxes: in all three countries practices of this sort took place with the knowledge of just some or all of the officials. In France during the Bourbon and July monarchies there was often dispute over who had been named on the handwritten papers: in 1824, a certain 'Dupin ainé', universally known as such, was denied vital votes by officials when his full name was not written on the ballot paper. ${ }^{70}$

The examples might be multiplied. In the case of Britain's poor law system, papers might be summarily declared void; left undelivered or uncollected; or simply forged. In Leeds in 1857 'a gigantic system of fraud' was perpetrated by the Tory party, based on fabricating papers. ${ }^{71}$ Such problems were well-known among the political elite. When, in the same year, the Tory MP, Lord Robert Cecil (later Lord Salisbury), argued for the use of the poor law method in parliamentary elections, opponents invoked recent examples of maladministration in Marylebone, Lambeth, Preston and Leicester. ${ }^{72}$ In the US ballot stuffing became a fine art, including the concealment of papers under the false bottom of a ballot box and the use of 'kiss' or 'tissue' ballots. ${ }^{73}$ The latter technique involved folding thinner, smaller ballots inside a larger paper, prior to its insertion in a box; a good shake of the box was all that was required to ensure their separation. In 1878, several Democratic election managers in South Carolina went on trial for permitting the use of kiss ballots, which had resulted in more ballot papers than registered electors. ${ }^{74}$ Similarly, in 1887 , an investigation was launched into a State Senate contest in Hudson County, New Jersey, where it was revealed that over 1,800 illegal papers had been cast, most of them tissue ballots. ${ }^{75}$ 
The public nature of balloting meant that voters were susceptible to bribery and intimidation. Even in France prior to 1848, where the use of billets prepared outside the assembly was forbidden, pre-prepared papers were touted both within and outside the courthouses and town halls that served as venues. ${ }^{76}$ In British municipal elections, bribery took place which recalled that practised in parliamentary contests. In 1858, over 800 papers were filled out by the Newcastle Ratepayers' Association and distributed to the homes of electors in the Westgate ward; on the day of election they were treated to beer, provided they voted for the Tory candidate. ${ }^{77}$ Defeated candidates had the right to challenge results and inspect the papers; but in most boroughs it seems that corruption of this sort was tolerated by both the Liberal and Tory parties.

In the US especially, cultures of corruption were highly variable and were more or less subtle depending on context and degrees of party factionalism and the social and ethnic make-up of the population. Outside of cosmopolitan city centres, most elections were peaceful, if not without bribery and influence. Even so, tactics of violence and intimidation were not uncommon. Following the Civil War, for instance, black voters were routinely bullied into voting for Democratic candidates in southern states such as Louisiana and Georgia. ${ }^{78}$ The same kind of tactics appeared in France after 1848, where attention shifted from the interior space of the electoral assembly to the entrance and adjacent streets and squares. Those touting papers, whether handwritten or printed, might include government employees, whose presence was especially pronounced during the Second Empire (1852-70). Otherwise the task was performed by candidates and agents, who would tour the constituency or gather outside the polling station, producing scenes denounced by the parliamentarian Lefèvre-Pontalis in 1902 as a 'veritable fairground', with voters accosted on all sides as they made their way to vote. ${ }^{79}$

As in the US, it was poorer, illiterate voters who were most susceptible to intimidation. In 1848 republicans in the Ardèche were accused of frisking voters before they entered the polling station; and then, if they were about to use an opposing list, of 'tearing up the ballot paper and replacing it with another'. ${ }^{80}$ Conduct of this sort persisted. In Brittany, in 1902, voters from some rural hamlets were unwilling to run the gauntlet of partisan agents in the neighbouring town, and so failed to vote; elsewhere there were reports of electors 'brigaded' into groups, given bulletins and marched to the polls. ${ }^{81}$ Voting with printed papers was hardly secret and in some instances an elector's ballot was open to the scrutiny of various agents, including candidates, government officials and social superiors. A splendid example of the conflicting pressures to which a voter might be exposed is furnished by a report made in 1848 by a tax official in the village of Vabres in the south-western department of the Tarn:

I was crossing the floor of the polling station ... when I encountered M. Barthès, a voter from the commune of Saint-Pierre. I asked to see his ballot paper and he replied that his parish priest, Bousquet, had forbidden him from showing it to anyone. I pointed out to him that he should not keep any secret from me, so he gave me the paper ... He then said to me, "our priest is much too attached to this list to allow it to be completely altered, but cross out the name at the bottom and replace it with one of your own choice", something which I did immediately. I had only just given the amended paper back to Barthès, who had not had time to put it back into his pocket, when the priest returned and took it from him, tore it up and said, "what are you up to, you wretched man"' Barthès was then handed another ballot paper and I was berated for behaving so badly. ${ }^{82}$

Myriad, if often intimate, social encounters thus took place around ballot papers cast in this public fashion. Any voter might find himself variously monitored, cajoled and admonished - as well as threatened with violence. 
At the same time, the very design of ballot papers opened up or closed down possibilities of this sort. The variations that emerged in the US have been documented at length. ${ }^{83}$ The use of coloured papers was one means of enhancing their publicity; and though some ballots might simply list a full slate of candidates, others might include a party emblem, a party slogan, or an etched profile of the presidential candidate (Fig. 3). Similar tactics emerged in Britain at the local level, where papers were supplied by party committees, either before the election or outside the polling place. In November 1835, during the first elections held under the Municipal Corporations Act, voters in Bristol were presented with papers prepared by the Liberal (Whig) party and filled out in pencil; electors only had to write over the pencil in ink and sign the paper. ${ }^{84}$

Elsewhere, American-style tickets were used, as in Poole and Shrewsbury, where Tories and Reformers touted different coloured lists. ${ }^{85}$ Illiterate voters might have no idea whom they were voting for. ${ }^{86}$ Likewise, under the Hobhouse regulations, party supporters could assemble in and around the polling place, making it easy to monitor how votes were being cast prior to the count. 'We knew perfectly well by the colour of the papers put in and the persons coming to vote, which party had obtained victory', noted one observer of elections held in 1834 in the parish of St George, London, where blue and green lists were used. ${ }^{87}$

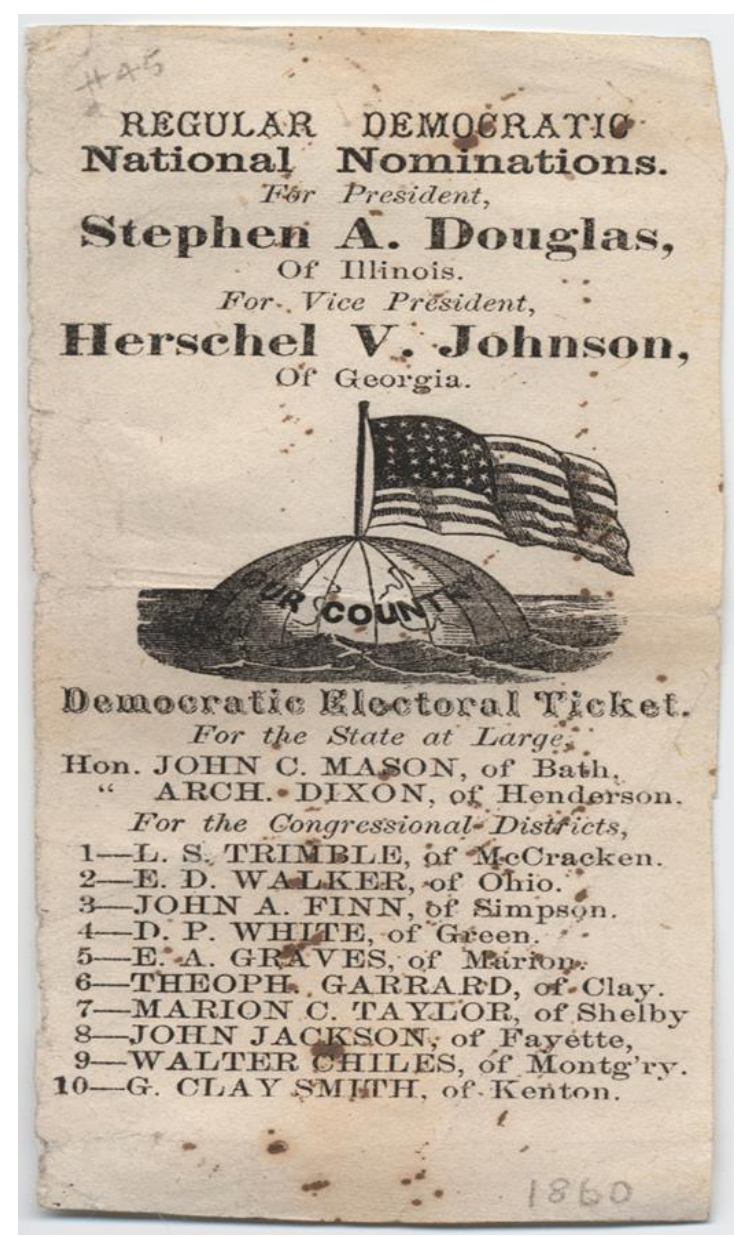

Figure 3: A state-wide Democratic ticket for Kentucky published during the 1860 presidential election. Cornell University Political Americana Collection, 2214.BA0045. 
5. Counter-tactics: None of these tactics escaped the notice of electoral officials, local and national authorities, competing parties, or indeed voters. Each corrupt tactic provoked a regulatory counterstrike, though all proved more or less unsuccessful. In 1867, the London-based Poor Law Board issued an Order which allowed party agents to accompany the local officials charged with delivering and collecting the papers. ${ }^{88}$ Yet problems persisted. Figures for the Chorlton Union in Manchester during the period 1868 to 1878 , where over 20,000 votes were up for grabs at each election, indicate that anything between 21 and 34 per cent of papers were not delivered in each of the Union's four townships. ${ }^{89}$ Innovations were also made to the design of ballot boxes. In the 1850s various tamper-proof receptacles emerged in California, including glass boxes and boxes made of see-through wire mesh; but they were seldom used. Likewise, 'balloting glasses or boxes' were prescribed in the 1855 Metropolis Local Management Act, but there is no evidence that 'glasses' were ever used in Britain. ${ }^{90}$

The papers themselves formed another element of regulation. In Britain it was not until 1872 when the appearance of ballot papers attracted significant debate. In the US and France, by contrast, measures designed to standardize - and so anonymize papers long-predated the advent of secure, technologized secrecy. The first innovations of this sort emerged in the US. In 1831, when the state of Maine formally legalized tickets, it also prohibited the use of coloured papers and the inclusion of any distinguishing marks other than the names of candidates. Similar laws were passed elsewhere, including in Connecticut and Indiana in 1867; California and Illinois in 1872; and Florida and Missouri in $1877 .{ }^{91}$ France banned coloured papers in 1848, just as electors began using papers prepared outside an assembly. Yet, in both France and the US, parties responded with counter-tactics of their own. There were different shades of white; different thicknesses of paper; and different fonts; and all were exploited by way of distinguishing papers. In the Haute-Garonne in 1869 efforts by one candidate to produce a similar looking paper to that of his opponent - and so protect his supporters led the opponent to print fresh bulletins on the eve of the poll. ${ }^{92}$

It could be that some electors secured a degree of secrecy when casting their ballot, should they have chosen to prepare their own paper, conceal it from agents and then pass it to the officials folded. But most chose not to do so and it was difficult in any case to hide subtle differences of texture and shade from the officials that deposited the papers in receptacles. Equally, parties were not always able to control fully who appeared on their papers. In the US, 'knifing' emerged as a recognised practice, normally as a product of intra-party conflicts. Here district leaders would remove (or 'knife') the party-sponsored candidate from the tickets they distributed and replace him with one of their own preference, thus allowing renegade contenders to score a victory. ${ }^{93}$ Electors themselves might strike out the names of particular candidates and write in alternatives, thereby 'splitting' the ticket. In general, as Richard Bensel has suggested, local agents were more concerned with the fate of their own candidates than the ticket as a whole; and when and where tickets were split it normally meant that a concerted effort had been made to break up a 'party slate'. Crucially, however, this was by no means a widespread tactic and split papers rarely exceeded five per cent of the total cast. ${ }^{94}$ The vast majority of voters cast their tickets 'straight', in keeping with the wishes of parties.

6. Hands and voices: Finally, in some places hands and voices continued to be used; only in France do we find something like a total commitment to using paper. Authorities 
in Britain and the US were more pragmatic, especially for minor offices where there was little or no contestation. In the US, balloting might still be optional at the local level, just as it had been in the seventeenth and eighteenth centuries. This was the case even in New England, home to some of the first innovations in written balloting. 'In our ordinary town elections, as you know, if a ballot is not called for, a vote is frequently put by show of hands or by ayes and nays', wrote one resident of Kingston, Rhode Island in 1870 in response to a committee of British radicals seeking information on practices abroad. ${ }^{95}$ Similarly, British highway boards and burial boards continued to conduct annual elections via a show of hands. Each made for a kind of microcosm of practices employed pre-1872 at the parliamentary level, for in both cases an open poll could take place if demanded. ${ }^{96}$ The rationale was a practical one: it was the quickest and cheapest way of conducting elections that were rarely controversial. The exemption of university seats from the 1872 Ballot Act is perhaps the best instance of the weakness in Britain of any philosophical commitment to voting in secret; and the number of university seats expanded rather than diminished between the 1860s and 1910s. Another is the method of voting used for the election of parish councils. Established in rural areas in 1894, these small-scale local councils relied on the use of hands until 1948, where the rationale was once more one of convenience. ${ }^{97}$

Pre-secrecy, then, there was considerable innovation among the three 'core' nations examined here, not least the simple - but crucial - introduction of ballot papers on a large scale. The opposition between open/oral voting on the one hand, and secret/paperbased voting on the other, fails to grasp anything of the plethora of options explored at the time. To be sure, the material form of the ballot paper at once solved and created problems, working in both directions at once: whilst it opened up and extended electoral participation, including to illiterates, it also enabled new forms of party-based conflict and control. Locked in this contradictory movement, the ballot paper thus became a hugely inventive site of ongoing experimentation and manipulation. Even so, there was no linear process of electoral privatisation at work: secrecy remained a minority demand, whilst voting remained a more or less public act.

\section{Balloting in secret: official papers}

Crucially, just as the use of paper-based technologies became more widespread so it became more politicized - more an object, that is, of political argument and parliamentary struggle. Indeed, here too, when it came to matters of principle, there was no linear shift or convergence regarding the ethics of voting in secret. In fact, arguments in favour of open voting flourished as never before during the nineteenth century, just as absolute secrecy was promoted as one solution to problems of electoral corruption and disorder. The arguments have been detailed at length: among others, that open voting was manly and brave, and so 'un-English', 'un-French' or 'un-American'; that the vote was a public trust that should be discharged accordingly; that voters should be just as accountable as those they were electing; and that any influence that was exercised, especially on the part of social superiors, was entirely legitimate. The idea that the voter was an 'individual', disembedded from the society in which he lived, was by no means assumed by all protagonists. ${ }^{98}$ 
To be sure, there is some evidence of arguments in favour of secrecy on the grounds that it was a good in and of itself. In Britain radicals occasionally made the argument that the vote was a matter of 'personal privacy' and of no intrinsic interest to others. In France, 'secrecy' and 'liberty' were sometimes couched together in this context ('le secret et la liberté'). But the arguments in favour of secrecy were by and large as follows: that (a) it was the best means of protecting the voter from bribery, intimidation and violence, and so enhancing his independence; and (b) that it would help to secure more orderly, cheaper elections, cutting down on electoral expenses for parties and local authorities alike. However, 'corruption' and 'independence' had various meanings and the question could be argued either way in these terms. On the one hand, secrecy might prevent corruption, understood as bribery, undue influence and intimidation; but on the other hand, this same secrecy, so it was argued, also corrupted the voter as an independent citizen, undermining his sense of public duty and forcing him to perform unmanly, deceitful and slavish acts.

There were some crucial differences in how reform was conceived and debated, and thus implemented. In Britain and the US reformers would eventually look towards the example of Australia, which besides introducing secrecy also imposed standardized, 'official' ballot papers, as opposed to handwritten and/or partisan printed ones. In Britain it was applied in parliamentary and municipal elections in 1872 and later to poor law, school board and county council elections (though not, as noted above, to parishes or university seats). In the US, Australian-style balloting was first introduced in Louisville, Kentucky and Massachusetts in 1888, and by 1892 it was in use in roughly three-quarters of states. ${ }^{99}$ The South was a different matter: by 1910 Georgia and South Carolina had yet to reform their voting practices - still in the 1930s the latter state was without any form of Australian ballot law, continuing to rely instead on printed ballots cast publicly.

In France, by contrast, the use of uniform bulletins was altogether more controversial. Indeed, it was just as critical as the question of secrecy and helps to explain why the French eventually, in 1913, opted for multiple papers (one for each candidate or party list), coupled with envelopes and cubicles (isoloirs), despite being aware of the Australian example. The use of official bulletins was first mooted in 1890, just a year after official candidatures had become compulsory, and was frequently promoted thereafter. Yet the measure encountered overwhelming opposition up to 1913, principally because of misgivings about the imposition of official candidates and the threat this posed to voter sovereignty. It was not until 1924 when papers printed by candidates or prepared by electors were finally declared illegitimate by France's electoral authorities. ${ }^{100}$

Even so, the broad point that absolute secrecy was regarded with ambivalence and suspicion is valid. It is striking that even reformers conceded that in principle open voting was the best kind of voting. Ultimately, it seems that the adoption of the secret ballot was a pragmatic decision; at any rate, certainly one that was conflicted on matters of principle. A case in point is Britain, where reform at the parliamentary level threatened a drastic switch from open polling to fully secret voting. There were reluctant, dissenting voices even within the Liberal Party, which eventually passed the 1872 Ballot Act. Much like Tories and the revered radical J.S. Mill, the Prime Minister, William Gladstone, considered the vote a public trust which should be enacted openly. What focused minds was the passage of the 1867 Reform Act, which almost doubled the parliamentary electorate, so that it stood at roughly two and half million males. In 
1869 , a select committee was convened to inquire into parliamentary and municipal electioneering, and in the following year reported in favour of secret voting.

Significantly, though mention was made by witnesses of their attachment to open voting - the likes of Mill and Lord Palmerston were invoked now and again - the testimony focused on other matters: public disorder, inconvenience, administrative confusion, bribery, rising election costs and how best 'to protect the voter'. At least one of those who gave evidence regarded a secret ballot as a 'necessary evil'. ${ }^{101}$

Much, then, depended on the material details; or in this case, not just the ballot paper but also who or what printed it, and how and where it was marked - eventually the 'polling booth' or the curtained isoloir. In the case of each country, franchises would continue to expand, eventually extending to women; and during the 1960s access to secure secret balloting was elevated to the status of a global 'human right' by the United Nations, to the exclusion of voting openly, which had been rendered an offence in Britain, France and the US. Yet it would be wrong to draw too strong a divide between pre- and post-secrecy electoral cultures, at least in terms of the ballot paper as a particular technological element. For if formerly the ballot paper was at once an object and a product of partisan struggle and manipulation, then the same remained true of its secretive successor.

As we might expect, old habits lingered hard. There was no immediate diminution in levels of bribery and maladministration. In Britain there was a marked increase in the number of petitions following the 1880 general election, prompting the passage of a more robust Corrupt Practices Act in 1883, which did eventually stamp out the worst excesses of treating and partisan employment. ${ }^{102}$ In the US, where the situation was still more dismal, cases of voter personation and ballot stuffing continued to be heard long into the interwar period, as Tracy Campbell in particular has detailed. ${ }^{103}$ Finally, though the advent of secrecy seems to have diminished levels of serious public disorder, this is not true of practices of intimidation. In France and the US party agents continued to loiter outside the polling place, lobbying and harassing voters. Meanwhile, in rural Britain landowners and employers would attend the village polling station, which might be festooned in partisan terms. In 1932, the Labour Organiser reported polling stations decked out in Tory colours and Union Jacks, complete with pictures of Tory candidates. Labour's electoral literature would thus remind farmworkers and the like of the secrecy of their vote. The message 'Remember the Ballot is Secret!' was still being printed on Labour polling cards in rural areas on the eve of the Second World War. ${ }^{104}$

Just as important are the practices that determined the design of papers, as voters and parties alike developed various strategies by way of reasserting their control postsecrecy. A whole series of micro-practices and design features developed in order to counter persistent tactics of corruption - regulations in fact that still remain in Britain today. Crucial among these was the so-called 'Tasmanian dodge', first practised in colonial Australia. Unlike in the state of Victoria, where officials initialled each paper and added the voter's number from the electoral roll, voters in Tasmania and South Australia were able to cast ballots that were unmarked with their number and so fully secret and untraceable. 'Dodging' exploited just this and involved the theft of a paper by a bribed voter (who would cast a dummy) and its delivery to the person buying votes outside the polling place, who would mark it. The next bribed voter would then cast the marked paper whilst stealing another blank in order to continue the process. British reformers became aware of the ruse in the late 1860s, prompting a variety of possible 
solutions. The most novel of these was put before the Commons in 1870 by the Liberal MP E.A. Leatham, which involved the use of invisible ink (cobalt chloride) to distinguish foldable 'ballot cards' with the registration number of voters (Fig. 4). Other features of Leatham's card included the practice of erasing candidates' names and their presentation in party-coloured lettering in the interests of legibility. It is an interesting glimpse of what might have been in Britain.

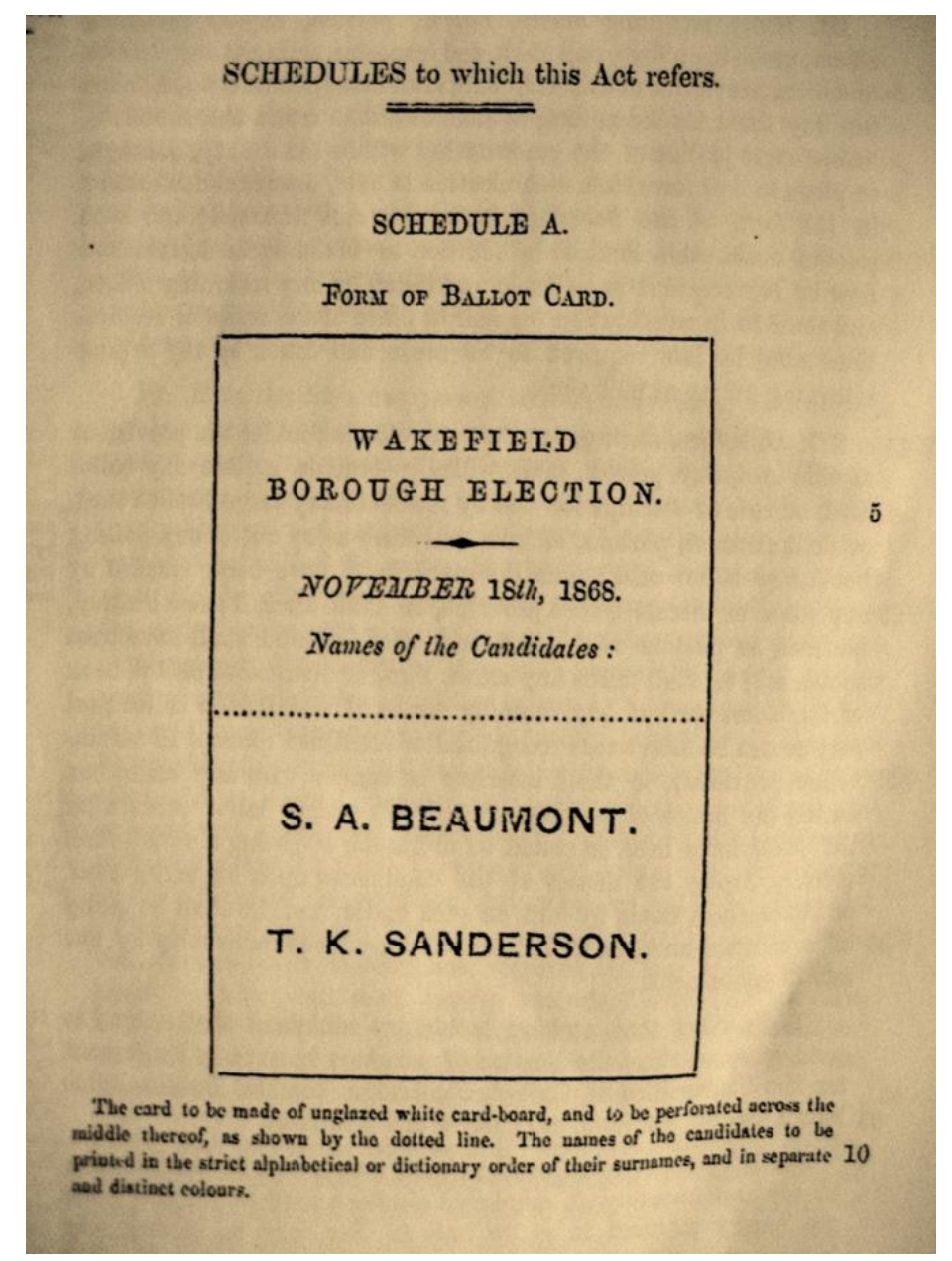

Figure 4: Leatham's ballot card which featured in an abortive bill the MP for Huddersfield introduced to the House of Commons in 1870. A Bill to Provide for the Taking of the Poll at Parliamentary and Municipal Elections by Ballot [Cd. 23] (1870).

In the end the British 1872 Ballot Act combined two Australian regulations: a modified variant of the Victorian practice of recording the voter's registration number, which involved the use of a stub and counterfoil; and the practice introduced in South Australia in 1858 where voters were required to mark a cross in a series of boxes placed next to candidates' names, which were listed and numbered on the paper in alphabetical order, according to surname. ${ }^{105}$ Similar regulations were developed in the US, even if not all states recorded the voter's registration number. By the $1940 \mathrm{~s}$, the twenty-five states that recorded the number did so using the British 'cheque-book system'. Yet, predictably enough, where no regulations of this sort were in place party agents and voters routinely practised the 'Tasmanian dodge'. Only in 1931 did the states of 
Pennsylvania and Ohio introduce the use of stubs and counterfoils to deter "chain voting', as it was known in the US. ${ }^{106}$

In France and Britain, however, there was little dispute regarding the general format of official paper/s once adopted. In France this amounted to the simple printing of a candidate's name or a party list on a standardized slip of white paper. The only significant change in Britain came in 1969, when party affiliations were permitted to appear on the paper alongside candidates' names. In the US, by contrast, whatever dispute had surrounded the adoption of the Australian ballot shifted to focus on its regulation. The use of controversial 'anti-fusion laws' meant that a candidate's name could appear on the ballot paper in association with only one party label, thereby deterring cross-party collaboration between one of the two major parties and a smaller party. ${ }^{107}$ Similarly, the design of papers was subject to partisan wrangling. Two dominant patterns were used. ${ }^{108}$ Beginning with Massachusetts in 1888, some states adopted the 'office-block' pattern, which grouped the names of candidates and their party affiliations according to the position they were contesting, as displayed in descending order (national first, followed by state and local offices). By the 1940s it was in use in seventeen states and was widely thought to be conducive to 'split-ticket' voting, whereby an elector would alternate which party he voted for according to candidate and office. The alternative layout was known as the 'party-column' pattern, which first made its appearance in Indiana in 1889, where each party was given a separate column of offices with the party's name displayed at the top.

The complexities are immense in this instance, for each layout was open to exploitation by those parties that controlled state legislatures. ${ }^{109}$ The use of the partycolumn pattern was widely judged to be more accessible; yet it also facilitated casting a straight ticket, thus enhancing the power of parties. ${ }^{110}$ Such misgivings were not necessarily misplaced: some states, including Connecticut, Iowa and Wisconsin, provided a single box at the top of each column via which an elector could, with just a single cross, select an entire party list. Other states, including Alabama, Indiana and Utah, also allowed party emblems on ballot papers to further enhance their userfriendliness (Fig. 5). By the same token, the office-block pattern, though thought to encourage the casting of split ballots - and so reasoned, independent voting - was also known to constitute an obstacle to the participation of illiterate voters, especially foreign-born voters in the North and uneducated black voters in the South. Exclusionary tactics based on exploiting the office-block pattern were especially pronounced in the South, where in Arkansas in 1892 one Democratic campaign song declared: 'The Australian ballot works like a charm/It makes them think and scratch/And when a Negro gets a ballot/He has certainly got his match. ${ }^{111}$ Contemporaries were acutely aware of these ruses, amidst debates where it was easy to disguise partisan interests in ostensibly non-partisan rhetoric regarding voter independence. 'Maryland, a State which has a large Negro population ... has the pure Massachusetts [office-block] ballot,' noted one critic in 1910, 'except in eleven counties, where even the party designation is dropped and the several candidates stand simply as individuals.' He went on: 'Yet this outwardly impartial arrangement is the much execrated "trick ballot". Perfectly simple to anyone who can read and write ... these styles have been regarded simply as puzzles by illiterate Negroes and as subjects for party trickery by many of the politicians. ${ }^{112}$ Other 'tricks' included the use of Gothic lettering and the nomination of candidates with similar or identical names to those of opponents. 


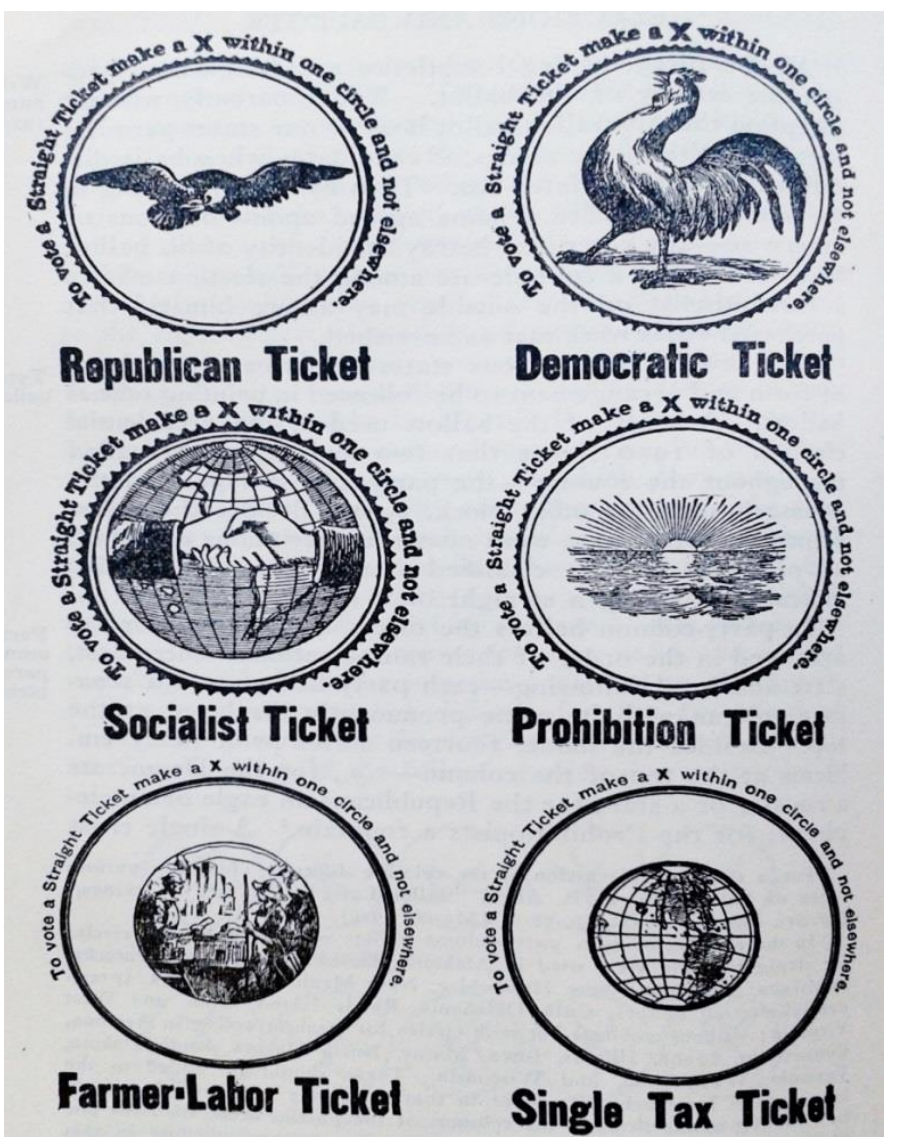

Figure 5: A picture of the party emblems that featured on the official ballot paper for Indiana's state elections of 1920, which permitted voting a straight ticket with just one cross. Robert C. Brooks, Political Parties and Electoral Problems (New York: Harper and Brothers, 1923), p. 396.

Yet there is also evidence of voters striking back and deliberately spoiling papers as a means of reclaiming some kind of independence. This seems to have been especially pronounced in France, where a peculiar tradition of invalidating ballot papers through either 'blank voting' or annotation has existed both pre- and post-secrecy. Failure to write a name on a paper was an established practice during the Revolution: a new set of regulations issued in 1798 decreed that all bulletins blancs and 'those ballot papers where the author can be identified, or which contain some kind of comment, are null and void'. ${ }^{113}$ The annotation of papers was given fresh stimulus after 1848, when voters were instructed to prepare their papers outside the polling station. This allowed them greater scope to fashion their own bulletins, and spoiling papers was especially widespread in the three plebiscites conducted under the Second Empire, when between 0.4 per cent (in 1851) and 1.3 per cent (1870) of the votes cast were rejected on these grounds. Of these, roughly 10 per cent were annotated, which in 1870 amounted to over 10,000 papers. ${ }^{114}$ Yet the practice was by no means confined to plebiscites and archival evidence testifies to its appearance in all sorts of elections, as voters sought to escape from the regulated anonymity of the bulletin. Annotations ranged from crude words and ditties to elaborate cartoons and mini-essays. A bulletin cast at Paris in 1852 concluded: 'The [Second] Empire is a backward step, no more possible in today's France than the monarchy of Louis XIV. Progress demands ... a Republic! ${ }^{115}$ 
One historian has equated these practices with 'delinquency', yet they can also be seen as assertions of voter independence and should certainly be distinguished from abstention. ${ }^{116}$ They required some kind of effort, after all, and there was more than a habitual attachment to the practice of handwriting following the explosion of printed papers after 1848. For some in fact it was matter of principle: as the liberal journalist Prévost-Paradol wrote in 1868 , 'Voting with a bulletin penned by oneself ... is the only practice worthy of a free people'. ${ }^{117}$ Indeed, the number of spoiled papers rose rather than diminished as the French electorate became more experienced and better educated, averaging 3 per cent of votes cast in legislative elections between 1881 and 1914 (Fig. 6). ${ }^{118}$ The inscription of slogans and messages doubtless continued after 1924, when official papers were made compulsory, though the relevant archives are currently unavailable for consultation. The retention of a few annotated bulletins cast in Algeria in the referendum on the foundation of the Fifth Republic in 1958 provides some evidence that the tradition survived. ${ }^{119}$

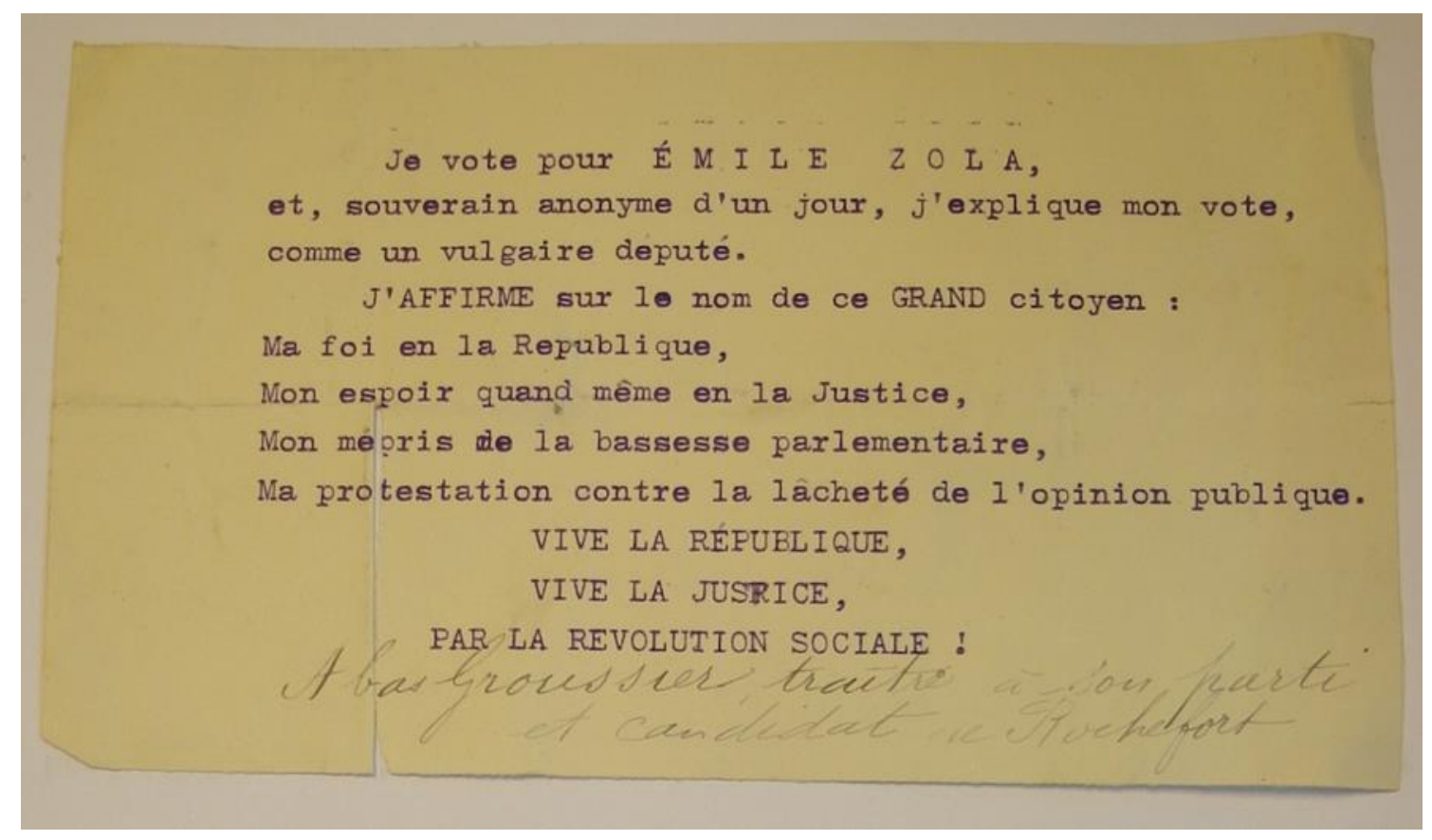

Figure 6: A bulletin cast in Paris during the 1898 legislative elections, at the height of the Dreyfus affair, which begins 'I am voting for Emile Zola and, as an anonymous sovereign for a day, I will explain my vote like a vulgar parliamentary deputy.' AN C5217, Procès-verbal d'élection, 8 May 1898.

The nearest analogue perhaps is the US practice of splitting tickets; but it is the French that have excelled in deliberately spoiling papers. Tactics include the longestablished one of depositing a blank piece of paper, as well as those made possible by the reforms of 1913 and 1924, in particular the casting of an empty envelope (from 1913) and the obliteration of a name on an official paper (from 1924). During the elections of 1958 and 1962 roughly 3 per cent of votes cast were declared nuls; and subsequent elections attracted still higher rates of invalidation, especially in the second round of presidential contests, when only two candidates remained in contention, as 
they still do today. ${ }^{120}$ The highest rate for a presidential race - almost 6.4 per cent - was achieved in the second round of the 1969 election, which was marked by the absence of a left-wing contender. Famously, Jacques Duclos, the disappointed Communist candidate who had scored 21 per cent of the vote in the first round, described the choice as 'c'est bonnet blanc et blanc bonnet'; or, very roughly, 'six of one and half a dozen of the other'. Similarly high levels of spoiling papers have been registered in recent years, including 6 per cent in 1995 (in the Chirac-Jospin run-off); 5.4 per cent in 2002 (ChiracLe Pen); and 5.8 per cent in 2012 (Sarkozy-Hollande). In the latter case this amounted to over two million voters announcing their distaste for both candidates at the ballot box. ${ }^{121}$

\section{Balloting abandoned: voting machines}

But do elections, even mass elections, really require ballot papers? Today there are two dominant paper-based methods used around the world, the Australian model and the French model. A further alternative, however, is to dispense with paper altogether and use some kind of voting machine. US states would become the pioneers on this front, where machines were first adopted in the 1890s - indeed, it might be described as the 'US model'; but Britain was home to the first proposals of this sort. In the 1830s the radical MP George Grote advocated the use of a machine which enabled voters to punch holes, secretly, in a card next to the names of their favoured candidates. ${ }^{122}$ Around the same time The People's Charter (1838), which helped to galvanize the Chartist movement, advocated the use of a box containing a series of holes, one for each candidate. Recalling the original meaning of the term 'ballot', voters were required to drop - again, secretly - a small ball into one of the holes, which then registered on a clock-like dial concealed beneath a lid. ${ }^{123}$ Further proposals emerged during the late 1860s, just prior to the 1872 Ballot Act. Five patents were registered in 1869 and in the same year the Liberal MP Charles Dilke advocated a 'system of ball voting' much like the one promoted by the Chartists. ${ }^{124}$

The objections were many, besides those against secrecy per se. In the 1870s even relatively simple machines using balls were rejected on account of their expense and liability to malfunction; and of course by this point electors were familiar with papers. ${ }^{125}$ In Britain the issue seems to have receded for almost one hundred years, before being taken up again in the 1980s and 1990s by the parliamentary Home Affairs Committee. ${ }^{126}$ More recently, electronic machines have been used in the 2000 London assembly elections and in the 2007 Scottish parliamentary elections; but so far the consensus is that the costs and technological risks of machine-based voting and counting outweigh those of the present paper-based system, which still retains, so it is argued, the trust of the public. Likewise in France the sceptical voices have so far outweighed the enthusiastic and on much the same grounds, despite occasional experiments, including the recent use of electronic voting by over a million voters in the presidential elections of $2007 .{ }^{127}$

Recent arguments, then, are of an entirely practical-administrative sort; and yet it is just these kinds of considerations that have spurred more than a hundred years of innovation in the US. The crucial difference was - and remains - the relative complexity of official papers. Whereas pre-secrecy, American voters could present a ready-to-use party ticket, under the Australian ballot they had to mark their paper in a 
polling booth; and these papers then had to be sorted, examined and counted. By the end of the century, US ballot papers routinely required voters to select upwards of twenty offices at various levels; and despite calls for their simplification these highly demanding papers remained common thereafter. In Chicago in 1930, for instance, voters had to mark a paper that presented fifty-nine posts in total, including thirty-two county and fifteen local judicial offices. ${ }^{128}$ Voting machines, by contrast, dispensed with ballot boxes and the handling, counting and cost of papers. 'Voting machines offer many advantages', noted one political scientist in 1923, 'chief among which are the speed and accuracy with which votes may be taken and counted. ${ }^{129}$ In Buffalo city, New York, in 1928, where over 218,000 voters had used machines, the results were announced within ninety minutes of the polls closing. ${ }^{130}$

Voting machines were first tried out in Lockport, New York in 1892 using the Myers Automatic Ballot-Cabinet. This was one of a number of competing models which involved electors, normally hidden behind a ' $U$ '-shaped curtain, registering their votes on a meter using levers, buttons and keys. Objections were raised on the grounds of their cost and complexity, and some questioned their constitutional validity - an issue not resolved by Congress until 1899, when it ruled in favour of allowing machines. ${ }^{131}$ But in subsequent decades machines were adopted across the US: roughly one sixth of all votes in the 1928 presidential election were cast mechanically. ${ }^{132}$ Also known as lever machines, they continued to be used long into the post-war period, up to and including the 2004 presidential election.

By 2004 three other types of machine were in use. Crucially, two of these punch card systems from the 1960s; optical scanning systems from the 1980s resurrected a ballot-style medium on which voters registered their choices, suggesting that it was the process of counting rather than selecting candidates that was the particular concern (in both cases it was sped up via electronic means). The most recent innovations, however, collectively known as direct-recording electronic voting systems, or DREs, have once more dispensed with the ballot paper in any shape or form. Like the lever machines that preceded them, DRE systems typically involve electors casting their votes through pressing buttons on an interactive interface; the difference is that this interface is electronic, thus enabling votes to be registered immediately as computer data. The first DRE device, known as the Video-Voter, underwent trials in Illinois in 1975 and single and multi-screen variants were pioneered thereafter, including touchscreen technologies during the late 1990s. ${ }^{133}$ Subject to modest use in the 1980s, their uptake increased steadily in the 1990s, before taking off in 2002. During the 2006 midterm elections they constituted almost 37 per cent of all voting methods used in the US, second only to optical scanners. ${ }^{134}$ Meanwhile, Australian-style balloting was becoming a minority pursuit. Practised in over 30 per cent of counties in 1988, this figure had fallen to roughly 10 per cent by the 2004 presidential election - a remarkable demise for a practice promoted only a hundred or so years earlier as means of reviving American democracy. ${ }^{135}$

\section{The materiality of mediated sovereignty}

How should sovereignty be expressed, whether confined to an elite or an adult population? Prior to the nineteenth century the preference was for the unmediated presence of participants, expressed via a unity of voices or a show of hands. Rousseau's 
democratic variant of this - crudely, his 'general will' - had no place for parties, secret balloting or even elections, which he regarded as a dilution of something purer: a citizenry at one with itself, unified in ongoing, face-to-face deliberations. The default setting, so to speak, was to resolve matters openly and in person, as part of an assembly; and ideally at least on a consensual basis. Slowly, in pockets to begin with, but then rapidly during the late eighteenth and early nineteenth centuries, the ballot paper emerged as a solution to a two-fold challenge to this settlement: ever-more assertive, organized conflict between competing groups animated by different interests and values, coupled with the need for civic order and numerical precision. Put another way, the practice of balloting in the early modern period and its extensive reworking in the wake of revolutionary upheaval points to a crucial consideration all too often obscured by the association between ballot papers and 'free and fair elections': namely, how best to manage socio-political conflict, so that collective decision-making can function in a way that is efficient and orderly. Secrecy arrived much later than ballot papers and the argument here is that it represents but a further twist in an established set of problems. Certainly on matters of principle there was much ambivalence, even opposition, regarding voting in secret. Part of its appeal in the three countries examined here was that secrecy promised quicker, quieter elections.

This is to put the matter crudely, for the problem of managing elections was complicated considerably by the advent of more inclusive franchises and organized political parties. This introduced three further facets: literacy and the ability of poorer voters to read and write their political choices; widespread, orchestrated forms of corruption and civic disorder; and finally, the bureaucratic-logistical conundrum of counting, handling and recording a growing volume of papers. Parties, voters and electoral authorities responded in hugely inventive and diverse ways, as electoral conflict became the norm. Both pre- and post-secrecy, regulatory tactics on the part of state authorities gave rise to counter-tactics on the part of parties and voters - and vice versa. Ultimately, as the example of the US shows, when and where deemed useful this could extend to abandoning ballot papers entirely. Otherwise put, if the broad problem is one of how to manage conflict, the institutional-practical solutions have been - and continue to be - entirely open and contingent. What works is what is best.

In this way, modern political agency, and in particular electoral agency, has been made possible only by assuming an inextricable relation to various kinds of technology, foremost among them the ballot paper. Though often discussed at the level of theory and philosophy, modern democracy is also an immense material-technological achievement. As advocates of the material turn suggest, 'little' things make 'big' ideas happen; and fewer are bigger or more widely promoted than democracy.

Two further points might be made here. The first is that if there is a materiality to politics then this is very much a historical phenomenon; and in the case of the ballot paper, a historical process deeply embedded in a broader switch to what we might call mediated forms of sovereignty, as opposed to the face-to-face assemblies and courts of the early modern period. Indeed, it is evidently the case that paper - and later secret, official - balloting needs to be situated within the development of a wider nexus of agents and practices that have come to define representative democracy, beyond just parties, voter registration and the provision of polling places. On the one hand, this extends to the development and reform of newspapers, national parliaments and established electoral cycles; on the other, to the development of bureaucracy and an administrative culture based on the currency of paperwork. Much like the advent of the 
ballot paper, all of these developments served to manage practices of collective governance and self-determination, whilst also naturalising the idea that power must be exercised through the mediation of other agents (journalists, candidates, bureaucrats, and so on) and associated technologies.

The second point is that if, conversely, there is a politics of materiality then this politics assumes different forms and intensities over time. The secret ballot is a case in point, for during the nineteenth century, and especially during its second half, fundamental questions were raised about whether secrecy promoted or denied the exercise of virtuous citizenship. And yet this line of questioning has now largely been forgotten, amidst a politics - such as it is - that centres on questions of cost and technological security. After the actor-network theorists who have inspired aspects of the material turn, we might say that the secret ballot has been 'black-boxed', rendered a natural, taken-for-granted aspect of our political modernity, when in truth its history is full of knotty conflicts and complex compromises. Put another way, the politics of materiality comes and goes, and is of varying degrees of profundity.

Finally, what of the present? In Britain and France the sceptics still hold sway, but in Brazil and India, two of the world's largest democracies, US-style DRE devices are now the order of the day. Since 2000 all Brazilian elections have been fully electronic, whilst in India, where they were first piloted in 1982, over half the electorate now uses voting machines. Some 400 million electors cast their votes electronically in the 2009 parliamentary elections. ${ }^{136}$ The project of making democracy work continues apace and it could be that the humble ballot paper will soon disappear, having finally served its purpose.

\footnotetext{
${ }^{1}$ Election fraud, including ballot stuffing, and various means of preventing the registration of voters, is an endemic practice in a number of democratic states, old and new. See especially R. Michael Alvarez, Thad E. Hall and Susan D. Hyde, ed., Election Fraud: Detecting and Deterring Electoral Manipulation (Washington, DC, 2008).

${ }^{2}$ Louis Massicotte, André Blais and Antoine Yoshinaka, Establishing the Rules of the Game: Election Laws in Democracies (Toronto, 2004), 122.

${ }^{3}$ Spencer D. Albright, The American Ballot (Washington, DC, 1942); L.E. Fredman, The Australian Ballot: The Story of an American Reform (East Lansing, 1968); and Roy G. Saltman, The History and Politics of Voting Technology: In Quest of Integrity and Public Confidence (New York, 2006).

${ }^{4}$ See in particular Alain Garrigou, Histoire sociale du suffrage universel en France, 1848-2000, rev. edn (Paris, 2002); Malcolm Crook and Tom Crook, 'The advent of the secret ballot in Britain and France, 1789-1914: From public assembly to private compartment', History 92 (2007): 449-471; Romain Bertrand, Jean-Louis Briquet and Peter Pels, ed., Cultures of Voting: The Hidden History of the Secret Ballot (2007); and Yves Déloye and Olivier Ihl, L'acte de vote (Paris, 2008).

${ }^{5}$ See in particular Mark McKenna, 'Building 'a closet of prayer' in the new world: The story of the 'Australian ballot', in Elections, Full, Free and Fair, ed. Marian Sawer (Annandale, 2001), 45-62.

${ }^{6}$ Malcolm Crook and Tom Crook, 'Reforming Voting Practices in a Global Age: The Making and Remaking of the Modern Secret Ballot in Britain, France and the United States, c. 1600-1950', Past \& Present 212 (2011): 199-237.
} 
${ }^{7}$ John Markoff, 'Where and When Was Democracy Invented?', Comparative Studies in Society and History, 41 (1999): 660-690.

${ }^{8}$ Patrick Joyce, The State of Freedom: A Social History of the British State since 1800 (Cambridge, 2013), chap. 4.

${ }^{9}$ Frank Trentmann, 'Materiality in the future of history: things, practices, and politics', Journal of British Studies 48 (2009): 307.

${ }^{10}$ Hubertus Buchstein, Offentliche und geheime Stimmagabe Stimmaggabe (Baden-Baden, 2000). Debate seems to have been especially intense in Britain. See especially Bruce L. Kinzer, The Ballot Question in Nineteenth-Century English Politics (New York, 1982) and Elaine Hadley, Living Liberalism: Practical Citizenship in Mid-Victorian Britain (Chicago, 2010), 175-228.

${ }^{11}$ Accounts include E. S. Staveley, Greek and Roman Voting and Elections (1972) and Josep M. Colomer and Iain McLean, 'Electing Popes: Approval Balloting and Qualified-Majority Rule', Journal of Interdisciplinary History 28 (1998): 1-22. Add Baumgartner?

${ }^{12}$ Overviews include Christopher R. Friedrichs, Urban Politics in Early Modern Europe (London, 2000), 12-17 and Hilary J. Bernstein, 'The Benefit of the Ballot? Elections and Influence in Sixteenth-Century Poitiers', French Historical Studies 24 (2001): 625-640.

${ }^{13}$ Adolphus Ballard, Chronicles of the Royal Borough of Woodstock (Oxford, 1896), 33-34.

${ }^{14}$ Mack P. Holt, 'Popular Political Culture and Mayoral Elections in Sixteenth-Century Dijon', in Society and Institutions in Early Modern France, ed. Mack P. Holt (Athens, GA, 1991), 98-116.

${ }^{15}$ Frank O'Gorman, Voters, Patrons and Parties: The Unreformed Electoral System of Hanoverian England, 1734-1832 (Oxford, 1989).

${ }^{16}$ Mark A. Kishlansky, Parliamentary Selection: Social and Political Choice in Early Modern England (Cambridge, 1986), 10-12.

${ }^{17}$ Contests were rare prior to the mid-seventeenth century; and though the number of contests picked up thereafter it was never more than 50 per cent. Between 1701 and 1831, roughly one third of elections were contested. O'Gorman, Voters, Patrons and Parties, 106-109.

${ }^{18}$ Kishlansky, Parliamentary Selection, 62, 180-183, and O'Gorman, Voters, Patrons and Parties, 130131.

${ }^{19}$ On this point see especially Catherine F. Patterson, Urban Patronage in Early Modern England: Corporate Boroughs, the Landed Elite, and the Crown, 1580-1640 (Stanford, CA, 1999), 90-92.

${ }^{20}$ B. Keith-Lucas, The English Local Government Franchise: A Short History (Oxford, 1952), 116-118; Kishlansky, Parliamentary Selection, chaps. 1-3; Bernstein, 'The Benefit of the Ballot?'

${ }^{21}$ Albright, The American Ballot, 9.

${ }^{22}$ Jacqueline Dumoulin, Le consulat d'Aix-en-Provence. Enjeux politiques, 1598-1692 (Dijon, 1992), 172.

${ }^{23}$ Reports from Commissioners: Sixteen Volumes-Corporations England and Wales: Appendix, Part II (Parliamentary Papers) [Cd. 116] (1835), 743-744. 
${ }^{24}$ Robert Descimon, 'Le corps de ville et les élections échevinales à Paris aux XVI ${ }^{\mathrm{e}}$ et XVII ${ }^{\mathrm{e}}$ siècles. Codification coutumière et pratiques sociales', Histoire, Economie, et Société 13 (1994): 509-512.

${ }^{25}$ Appendix to the First Report of the Commissioners: Part III, Northern and North-Midland Circuits (Parliamentary Papers) [Cd. 116] (1835), 1674-1675.

${ }^{26}$ Reports from Commissioners: Sixteen Volumes-Corporations, England and Wales: Appendix, Parts IV $\& V$ (Parliamentary Papers) [Cd. 116] (1835), 2895.

${ }^{27}$ Roger Chartier and Denis Richet, eds, Représentation et vouloir politiques. Autour des États-généraux de 1614 (Paris, 1982), 132.

${ }^{28}$ Bernstein, 'The Benefit of the Ballot?'

${ }^{29}$ Cortlandt F. Bishop, 'History of Elections in the American Colonies', Studies in History, Economics and Public Law: Volume III, ed., The University Faculty of Political Science of Columbia College (New York, 1893), 203-235.

${ }^{30}$ Robert J. Dinkin, Voting in Provincial America: A Study of Elections in the Thirteen Colonies, 16891776 (Westport, CT, 1977), 132-136.

${ }^{31}$ Ibid., 136-137.

${ }^{32}$ Edward M. Cook, Jr., The Fathers of the Towns: Leadership and Community Structure in EighteenthCentury New England (Baltimore, MD, 1998), 2-10. See also Michael Zuckerman, Peaceable Kingdoms: New England Towns in the Eighteenth Century (New York, 1970), chap. 5.

${ }^{33}$ Bishop, 'History of Elections in the American Colonies', 127-140.

${ }^{34}$ Ibid?Bishop, 'History of Elections in the American Colonies', 147-149; Cook, Fathers of the Towns, 4-5.

${ }^{35}$ H.T. Dickinson, 'The Precursors of Political Radicalism in Augustan Britain', in Britain in the First Age of Party, 1680-1750: Essays Presented to Geoffrey Holmes, ed. Clyve Jones (1987), 74.

${ }^{36}$ Cook, Fathers of the Towns, 5-10; Dinkin, Voting in Provincial America, 137-138.

${ }^{37}$ Bishop, 'History of Elections in the American Colonies', 168-174; Dinkin, Voting in Provincial America, 138.

${ }^{38}$ Albert Babeau, La ville sous l'ancien régime (Paris, 1880), 65.

${ }^{39}$ Règlement pour l'administration des villes et principaux bourgs du royaume, 1764, in M. Bordes, La réforme municipale du contrôleur-général Laverdy et son application, 1764-1771 (Toulouse, 1968), 291, and idem, L'administration provinciale et municipale en France au XVIII' siècle (Paris, 1972), 336. ${ }^{40}$ Jérôme Mavidal and Émile Laurent, eds, Archives parlementaires de 1787 à 1860, Première série (1787-1799) (Paris, 1867-), vol. 1, 430, 449, 472.

${ }^{41}$ Règlement pour l'exécution des lettres de convocation, 24 January 1789, in Armand Brette, ed., Recueil de documents relatifs à la convocation des États-généraux de 1789, 4 vols (Paris, 1894), vol. 1, 85.

${ }^{42}$ Richard Hofstadter, The Idea of a Party System: The Rise of Legitimate Opposition in the United States, 1780-1840 (Berkeley, CA, 1970); T.A. Jenkins, Parliament, Party and Politics in Victorian Britain (Manchester, 1996); and Raymond Huard, La naissance du parti politique en France (Paris, 1996). ${ }^{43}$ Archives parlementaires, vol. 10, 67-8. 
${ }^{44}$ Ibid., vol. 10, 564-71.

${ }^{45}$ Crook and Crook, 'The advent of the secret ballot in Britain and France, 1789-1914': 450; Jacques Godechot, Les Constitutions de la France depuis 1789 (Paris, 1973), 84.

${ }^{46}$ Malcolm Crook, 'Confiance d'en bas, manipulation d'en haut: la pratique plébiscitaire sous Napoléon (1799-1815)', in L'incident électoral de la Révolution à la Ve République, ed. P. Bourdin et al. (ClermontFerrand, 2002), 77-87.

${ }^{47}$ John A. Phillips (ed. Philip Salmon), 'England's “'Other” Ballot Question: The Unnoticed Political Revolution of 1835', Parliamentary History 24 (2005): 152-153; and James Vernon, Politics and the People: A Study in English Political Culture, c. 1815-1867 (Cambridge, 1993), 16-22, 155.

${ }^{48}$ Robert E. Zegger, John Cam Hobhouse: A Political Life, 1819-1852 (Columbia, MO, 1973), 155-156.

${ }^{49}$ The Municipal Corporation Reform Act: An Abstract of the Act (1835).

${ }^{50}$ Phillips, 'England's “Other” Ballot Question', 154-157.

${ }^{51}$ William Cunningham Glen, The Law Relating to the Public Health and Local Government (1858), 3648; Edmund Humphrey Woolrych, The Metropolis Local Management Acts, with Introduction, Notes and Appendix (1863), 14; Hugh Owen, Jnr., The Elementary Education Act, 1870, with Introduction, Notes, and Index, $4^{\text {th }}$ edn. (1870), 186-189.

${ }^{52}$ Saltman, The History and Politics of Voting Technology, 82.

${ }^{53}$ Abram C. Bernheim, 'The Ballot in New York', Political Science Quarterly 4 (1889): 130-1.

${ }^{54}$ Robert J. Dinkin, Voting in Revolutionary America: A Study of Elections in the Original Thirteen States, 1776-1789 (Westport, CT, 1982), 102.

${ }^{55}$ Paul F. Bourke and Donald A. DeBats, 'Identifiable Voting in Nineteenth-Century America: Toward a Comparison of Britain and the United States before the Secret Ballot', Perspectives in American History 11 (1977-78): 268-275.

${ }^{56}$ Godechot, Les Constitutions de la France, 105-6.

${ }^{57}$ Michel Brunet, 'The Secret Ballot Issue in Massachusetts Politics from 1851 to 1853', The New England Quarterly 25 (1952): 354-362.

${ }^{58}$ Cited in Vernon, Politics and the People, 156.

${ }^{59}$ Richard Franklin Bensel, The American Ballot Box in the Mid-Nineteenth Century (Cambridge, 2004), 9-14, 30-37.

${ }^{60}$ Malcolm Crook, 'Le candidat imaginaire ou l'offre et le choix dans les élections de la Révolution française', Annales historiques de la Révolution française 321 (2000), 91-110.

${ }^{61}$ Malcolm Crook, Elections in the French Revolution: An Apprenticeship in Democracy, 1789-1799 (Cambridge, 1996), 67-71.

${ }^{62}$ Alison Patrick, The Men of the First French Republic: Political Alignments in the National Convention of 1792 (Baltimore, 1972), 163-165.

${ }^{63}$ A[rchives] D[épartementales] Aveyron 1L582, Procès-verbal d'élection, June 1790.

${ }^{64}$ H. Baumont, 'Les assemblées primaires et électorales de l'Oise en 1792 (août-septembre)', Révolution française 47 (1901): 164-71. 
${ }^{65}$ Crook and Crook, 'The advent of the secret ballot', 461.

${ }^{66}$ Quoted in Albright, The American Ballot, 19.

${ }^{67}$ Saltman, The History and Politics of Voting Technology, 61-62; Albright, The American Ballot, 19-20.

${ }^{68}$ See Richard Franklin Bensel, The Political Economy of American Industrialization, 1877-1900

(Cambridge, 2000), 34-37, where he suggests that in counties across the US upwards of a quarter of all adult males were unable to read and write even by 1900 .

${ }^{69}$ Bensel, The American Ballot Box in the Mid-Nineteenth Century, 14-17, 39.

${ }^{70}$ Sherman Kent, The Election of 1827 in France (Cambridge, MA., 1975), 76-77, and idem, Electoral Procedure under Louis Philippe (New Haven, CT, 1937), 99-102.

71 'The Late Election of Guardians', The Leeds Mercury, Saturday, April 25, 1857.

72 'Voting Papers at Elections', The Leeds Mercury, Saturday, June 6, 1857; 'Voting Papers or the Pseudo-Ballot', The Liverpool Mercury, Monday, June 8, 1857.

${ }^{73}$ Dinkin, Voting in Revolutionary America, 104-105.

${ }^{74}$ Robert Goldman, 'A Free Ballot and a Fair Count': The Department of Justice and the Enforcement of Voting Rights in the South, 1877-1893 (New York, 2001), 68-70.

${ }^{75}$ Richard Patrick McCormick, The History of Voting in New Jersey: A Study of the Development of Election Machinery, 1664-1911 (New Brunswick, NJ, 1953), 172.

${ }^{76}$ Alexandre Pilenco, Les moeurs électorales en France. Régime censitaire (Paris, 1928), 258-68.

${ }^{77}$ Ibid., 55-56.

${ }^{78}$ Tracy Campbell, Deliver the Vote: A History of Election Fraud, An American Political Tradition, 1742-2004 (New York, 2005), 60-63.

${ }^{79}$ A. Lefèvre-Pontalis, Les elections en Europe à la fin du XIX siècle (Paris, 1902), vii.

${ }^{80}$ AN C1325, Protestation des électeurs de Privas, 24 April 1848.

${ }^{81}$ Garrigou, Histoire sociale du suffrage universel, 72 and 107; and P. Leroy-Beaulieu, Un chapitre des moeurs électorales en France dans les années 1889 et 1890 (Paris, 1890), 25.

${ }^{82}$ AN C1329, Percepteur de Vabres (Tarn) au juge de paix, 26 April 1848.

${ }^{83}$ See especially Fredman, The Australian Ballot, 20-31.

84 'Recent Municipal Elections', The Bristol Mercury, Saturday, 12 March, 1836.

${ }^{85}$ Philip Salmon, Electoral Reform at Work: Local Politics and National Parties, 1832 1841(Woodbridge, 2002), 227.

${ }^{86}$ Report from the Select Committee of the House of Lords Appointed to Inquire into the Operation of the Act 13 and 4 Vict. c. 99, for the Better Assessing and Collecting the Poor Rates and Highway Rates of Small Tenements, and of the Act of last Session, cap. 43, to Amend the Municipal Franchise in certain Cases (Parliamentary Papers) [Cd. 56] (1859): 31-32, 71-72, 120, 129-130.

${ }^{87}$ Ibid., 439.

${ }^{88}$ W.G. Lumley, The Poor Law Election Manual, $3^{\text {rd }}$ edn. (1867), 22-33.

${ }^{89}$ Report from the Select Committee on Poor Law Guardians, \&c., Appendix, No. 3, 318-319. 
${ }^{90}$ Edmund Humphrey Woolrych, The Metropolis Local Management Acts, with Introduction, Notes and Appendix (London: Shaw and Sons, 1863), 14.

${ }^{91}$ Albright, The American Ballot, 20-22.

${ }^{92}$ Cited in Patrick Lagoueyte, 'Candidatures officielles et pratiques électorales sous le Second Empire (1852-1870)', 5 vols, Université de Paris I, 1990, vol. 3, 872-73.

${ }^{93}$ On knifing see Mark Wahlgren Summers, Party Games: Getting, Keeping, and Using Power in Gilded Age Politics (Chapel Hill, NC, 2004), 205-206; and Francis S. Barry, The Scandal of Reform: The Grand Failures of New York's Political Crusaders and the Death of Non-Partisanship (New Brunswick, NJ: Rutgers University Press, 2009), 42-43.

${ }^{94}$ Bensel, The American Ballot Box in the Mid-Nineteenth Century, 31-32.

${ }^{95}$ Testimony to the Working of the Ballot by Eminent Authorities in the United States, France and Germany (Hawick, 1871), 13.

${ }^{96}$ The most detailed account of these practices is Report from the Select Committee on Poor Law Guardians, \&c.; Together with the Proceedings of the Committee, Minutes of Evidence and Appendix (Parliamentary Papers) [Cd. 297] (1878).

${ }^{97}$ Keith-Lucas, The English Local Government Franchise, 121-123.

98 The relevant literature is indicated above, in notes 3-6, and 11.

${ }^{99}$ Albright, The American Ballot, 26-9.

${ }^{100}$ Crook and Crook, 'Reforming Voting Practices in a Global Age', 235-236.

${ }^{101}$ Report from the Select Committee on Parliamentary and Municipal Elections (Parliamentary Papers) [Cd. 115] (1870).

${ }^{102}$ Kathryn Rix, “'The elimination of corrupt practices in British elections'? Reassessing the impact of the 1883 Corrupt Practices Act', English Historical Review, 123 (2008): 65-97.

${ }^{103}$ Campbell, Deliver the Vote, Part Two.

${ }^{104}$ Clare V. J. Griffiths, Labour and the Countryside: The Politics of Rural Britain, 1918-1939 (Oxford, 2007), 57-58.

${ }^{105}$ A detailed description of Australian practices can be found in Ballot (Australian Colonies): Paper Relative to the operation of the System of the Ballot in the Colonies (Parliamentary Papers) [Cd. 286] (1871).

${ }^{106}$ Albright, The American Ballot, 43-45.

${ }^{107}$ Howard A. Scarrow, 'Duverger's Law, Fusion and the Decline of American 'Third' Parties', Western Political Quarterly 39 (1986): 634-647.

${ }^{108}$ A useful summary is Joseph P. Harris, Election Administration in the United States (Washington, DC, 1934), 155-184.

${ }^{109}$ See especially Alan Ware, 'Anti-Partisan and Party Control of Political Reform in the United States: The Case of the Australian Ballot', British Journal of Political Science 30 (2000): 1-29.

${ }^{110}$ Harris, Election Administration in the United States, 157-159. 
${ }^{111}$ Quoted in John Crowley, 'Uses and Abuses of the Secret Ballot in the American Age of Reform', in Bertrand, Briquet and Pels, eds, Cultures of Voting, 59.

${ }^{112}$ Philip Loring Allen, 'The Multifarious Australian Ballot', The North American Review 191 (1910): 608.

${ }^{113}$ Loi sur les assemblées primaires et communales, 8 March 1798.

${ }^{114}$ Malcolm Crook, 'Un vote subversive? La pratique des bulletins annotés en France, 1848-1914', forthcoming, 2014.

${ }^{115}$ AN BII 1206B, P-V Paris, $15^{\mathrm{e}}$ arrondissement, 1852.

${ }^{116}$ Y.-M. Bercé, 'Les bulletins nuls, source de microsociologie électorale', Gazette des Archives 65 (1969): 82.

${ }^{117}$ L.-A. Prévost-Paradol, La France nouvelle (Paris, 1868), 55.

${ }^{118}$ Alain Lancelot, L'abstenionnisme électoral en France (Paris, 1961), 50.

${ }^{119}$ AN BII 1473, Situation d'Algérie, Sept. 1958.

${ }^{120}$ David B. Goldey, 'The French Referendum and Elections of 1962: The National Campaigns', Political Studies 11 (1963): 302.

121 'Deux millions de votes blancs et nuls soit 6 \% des votants', Le Monde, Monday, 7 May, 2012.

${ }^{122}$ Mrs Grote, The Personal Life of George Grote (1873), 109-10.

${ }^{123}$ The People's Charter (1838), schedules A and B, and 27-31.

${ }^{124}$ [Patent Office], Alphabetical Index of Patentees and Applicants for Patents of Invention, for the Year 1869 (1870), 549.

${ }^{125}$ See for instance Mr E.A. Leatham, The Ballot-Technically Considered (Manchester, 1871), 12-13.

${ }^{126}$ Home Affairs Committee. Session 1982-83. Representation of the People Act 1949: Minutes of Evidence, Wednesday 16 February 1983 FONT (Parliamentary Papers) [HC 32-ix] (1982/83); Home Affairs Committee. Third Report. Electoral Counting Methods. Report together with the Proceedings of the Committee, Minutes of Evidence and Appendices FONT (Parliamentary Papers) [HC 49] (1991/92). ${ }^{127}$ Nathalie Dompnier, 'Les ordinateurs de vote : une nouvelle donne politique et technique', Revue politique et parlementaire, 1044 (2007), 50-3.

${ }^{128}$ Fredman, The Australian Ballot, 124-125.

${ }^{129}$ Robert C. Brooks, Political Parties and Electoral Problems (New York, 1923), 407.

130 'Voting Machines', The Encyclopaedia Britannica, Fourteenth Edition: A New Survey of Universal Knowledge, Volume 23, Vase to Zygote (New York, 1929), 259.

${ }^{131}$ Saltman, The History and Politics of Voting Technology, 117-118.

132 'Voting Machines', The Encyclopaedia Britannica, Fourteenth Edition, 259.

${ }^{133}$ Saltman, The History and Politics of Voting Technology, 164-166.

${ }^{134}$ Election Data Services, Inc., 2006 Voting Equipment Study, October 2, 2006 [accessed at www.electiondataservices.com, 13.1.2013] 
${ }^{135}$ R. Michael Alvarez and Thad E. Hall, Electronic Elections: The Perils and Promises of Digital Democracy (Princeton, NJ, 2008), 21; Paul S. Harrison et al., Voting Technology: The Not-So-Simple Act of Casting a Ballot (Washington, DC, 2006), 10.

${ }^{136}$ Massicotte, Blais and Yoshinaka, Establishing the Rules of the Game, 129; Christophe Jaffrelot, 'Voting in India: Electoral Symbols, the Party System and the Collective Citizen', in Bertrand, Briquet and Pels, eds, Cultures of Voting, 95-97. 